\title{
Acenaphtho[5,6-cd]-1,2-dichalcogenoles and their Platinum Complexes
}

\author{
Louise M. Diamond, Fergus R. Knight, David B. Cordes, Andrew C. C. Ward, Alexandra M. Z. Slawin \\ and J. Derek Woollins*
}

EaStCHEM, School of Chemistry, University of St Andrews, St Andrews, Fife, KY16 9ST (UK)

Fax: (+44)1334-463384

E-mail: jdw3@st-and.ac.uk

Keywords: Chalcogen / Acenaphthylene / Platinum / Metathesis / X-ray Structure/ Coordination complex

\begin{abstract}
A related series of bis(phosphine) platinum complexes 1-5 and 6-8 bearing dichalcogenate acenaphthylene ligands have been synthesised. The chalcogen-chalcogen bonds in the parent acenaphtho[5,6-cd]-1,2-dichalcogenoles $\left(\right.$ AcenapylE $E_{2} ; \mathbf{L} 1 \mathrm{E}=\mathrm{S}$, L2 E = Se; Acenapyl = acenaphthylene-5,6-diyl) were reduced with two equivalents of lithium triethylborohydride to form the dilithio-species. Metathetical addition of the lithium dichalcogenate species to a suspension of the appropriate cisdichlorobis(phosphine)platinum in THF resulted in the formation of platinum (II) complexes $\left[\mathrm{Pt}\left(5,6-\mathrm{AcenapylE}_{2}\right)\left(\mathrm{PR}_{3}\right)_{2}\right](\mathbf{1}$ $\mathrm{E}=\mathrm{S}, \mathrm{R}_{3}=\mathrm{Ph}_{3} ; 2 \mathrm{E}=\mathrm{S}, \mathrm{R}_{3}=\mathrm{Ph}_{2} \mathrm{Me} ; 3 \mathrm{E}=\mathrm{S}, \mathrm{R}_{3}=\mathrm{PhMe}_{2} ; 4 \mathrm{E}=\mathrm{S}, \mathrm{R}_{3}=\mathrm{Me}_{3} ; 6 \mathrm{E}=\mathrm{Se}, \mathrm{R}_{3}=\mathrm{Ph}_{3} ; 7 \mathrm{E}=\mathrm{Se}, \mathrm{R}_{3}=\mathrm{Ph}_{2} \mathrm{Me}_{2} \mathbf{8}$ $\mathrm{E}=\mathrm{Se}, \mathrm{R}_{3}=\mathrm{PhMe}_{2}$ ). The dilithio-species of $\mathbf{L} \mathbf{1}$ and $\mathbf{L} \mathbf{2}$ were also reacted with (1,5-cyclooctadiene)platinum(II) dichloride. This reaction was successful with $\mathbf{L 1}$ resulting in the formation of platinum complex $\left[\operatorname{Pt}\left(5,6-A c e n a p y l S_{2}\right)(C O D)\right](5)$. Complexes 1-3 and 5-8 have been fully characterised, principally by multinuclear magnetic resonance spectroscopy, IR and MS. Secondary isotopomer effects create complex satellite systems observed in both the ${ }^{31} \mathrm{P}\left\{{ }^{1} \mathrm{H}\right\} \mathrm{NMR}$ and ${ }^{77} \mathrm{Se} \mathrm{NMR}$ spectra of selenium complexes 6-8. X-ray structures were determined for L1, 1, 3 and 6 and analysed, where appropriate, by measuring the peri-distance, splay angle magnitude, peri-atom displacement, central naphthalene ring torsions and the geometry around the platinum centre. Platinum was found to adopt a distorted square-planar geometry in all three complexes. Complex 1 was found to have the greatest molecular distortion of all three complexes, showing that changing the phosphine group and also the chalcogen has a noticeable effect. Comparisons were made between $\mathbf{6}$ and our previously reported $\left[\mathrm{Pt}\left(\mathrm{NapSe}_{2}\right)\left(\mathrm{PPh}_{3}\right)_{2}\right]$ and $\left[\mathrm{Pt}(\mathrm{AcenapSe} 2)\left(\mathrm{PPh}_{3}\right)_{2}\right]$ complexes; the level of distortion was found to decrease as the backbone is altered from naphthalene to acenaphthylene.
\end{abstract}

\section{Introduction}

The family of polycyclic aromatic hydrocarbons naphthalene, acenaphthene and acenaphthylene offer suitable rigid organic backbones with which to study non-bonded intramolecular interactions.[1,2,3] Heteroatoms that are substituted at the peri-positions in these systems (positions 1- and 8- of the naphthalene ring and positions 5- and 6- of the acenaphthene and acenaphthylene rings) are forced to occupy space that is closer than the sum of their van der Waals radii, allowing unique interactions to transpire between the bulky substituents. Hydrogen atoms can be accommodated in the peri-positions with ease because the non-bonded hydrogen distances in naphthalene, acenaphthene and acenaphthylene $(2.44 \AA$, $2.70 \AA$, $2.73 \AA)[1,2,3]$ are still greater than the sum of the van der Waals radii for two hydrogen atoms $\left(\Sigma \mathrm{r}_{\mathrm{vdw}}=2.18 \AA\right)$.[4] If these peri-hydrogens are replaced with larger substituents though, steric hindrance is expected as there is not enough space for the larger groups to be accommodated without a significant overlap of orbitals.[5] Despite this, a great array of peri-substituted 
naphthalenes[6] have been prepared due to the system's ability to relieve strain through the deformation of the organic framework or by the existence of attractive interactions operating between the two substituents. While some peri-substituted acenaphthenes[7] and acenaphthylenes[8] have been prepared they have received much less attention than naphthalene systems.[6]

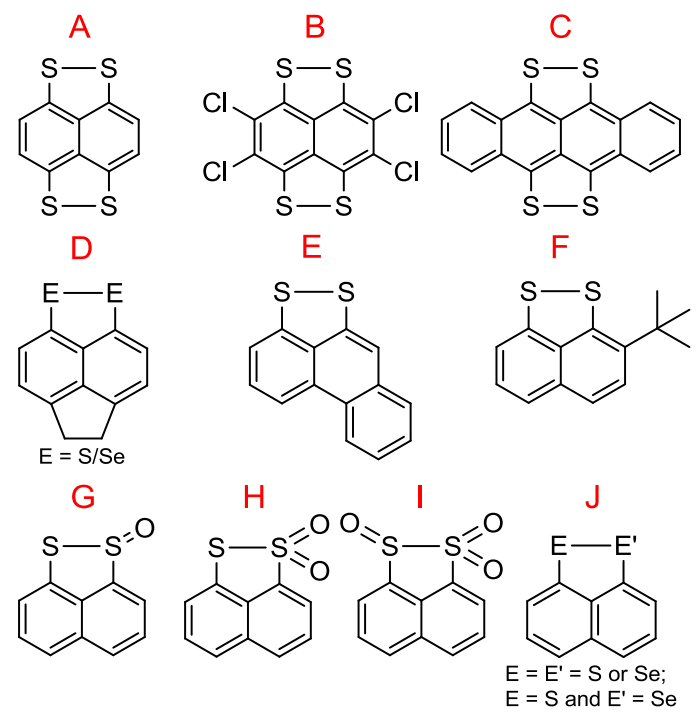

Figure 1. Peri-substituted dichalcogenole ligands previously utilised in the formation of platinum complexes. $[9,10,11]$

In the late 1970's and early 1980's Teo and co-workers[9] coordinated tetrathionaphthalene (TTN; Figure 1 A), tetrachlorotetrathionaphthalene (TCTTN; B) and tetrathiotetracene (TTT; C) to a $\mathrm{Pt}\left(\mathrm{PPh}_{3}\right)_{2}$ centre through oxidative addition reactions with $\left[\mathrm{Pt}\left(\mathrm{PPh}_{3}\right)_{4}\right]$. Due to the structural similarity of these compounds to naphthalene, we used this oxidative reaction to study the coordination chemistry of 1,8-dichalcogen naphthalenes and related species to platinum bisphosphines.[10] The acenaphthene (D), phenanthrene (E), 2-tert-butyl-substituted naphthalene dithiolate (F) and the oxides of naphtho[1,8-cd]1,2-dithiole (G-I) (with the exception of the tetra oxide) were successfully complexed to platinum through oxidative addition of $\left[\mathrm{Pt}\left(\mathrm{PPh}_{3}\right)_{4}\right] .[10]$ The naphtho[1,8-cd][1,2]dithiole, naphtho[1,8-cd][1,2]diselenole and naphtho[1,8-cd][1,2]selanthiole platinum complexes were also prepared through a metathetical reaction of the dilithio-1,8-dichalcogenato naphthalene (J), but with $c i s-\left[\mathrm{Pt}\left(\mathrm{PR}_{3}\right)_{2} \mathrm{Cl}_{2}\right]$ (where $\mathrm{R}=\mathrm{Ph}$ or $\mathrm{Me}$ ) in $\mathrm{THF}$ at room temperature.[10]

We furthered this study in 2013 by preparing and fully characterising six platinum bis(phosphine) complexes constructed from 5,6-dihydroacenaphtho[5,6-cd]-1,2-dithiole $\quad\left[\right.$ AcenapS $\left._{2}\right]$ and 5,6-dihydroacenaphtho[5,6-cd]-1,2-diselenole [AcenapSe $e_{2}$ (D).[11] These complexes were prepared through metathetical reaction of the dilithio salt of the parent acenaphthene, with a suspension of cis- $\left[\mathrm{Pt}\left(\mathrm{PR}_{3}\right)_{2} \mathrm{Cl}_{2}\right]$ (where $\mathrm{R}=\mathrm{Ph}_{3}, \mathrm{Ph}_{2} \mathrm{Me}, \mathrm{PhMe}_{2}$ ). Herein we build on the aforementioned studies through the preparation and structural analysis of seven analogous acenaphthylene based platinum bisphosphine complexes $\left[\mathrm{Pt}\left(5,6-\mathrm{AcenapylE}_{2}\right)\left(\mathrm{PR}_{3}\right)_{2}\right]\left(\mathrm{R}_{3}=\mathrm{Ph}_{3}: \mathrm{E}=\mathrm{S}\right.$ 1, Se 6; $\mathrm{R}_{3}=\mathrm{Ph}_{2} \mathrm{Me}: \mathrm{E}=\mathrm{S}$ 2, Se 7; $\mathrm{R}_{3}=\mathrm{PhMe}_{2}: \mathrm{E}=\mathrm{S}$ 3, Se 8; $\mathrm{R}_{3}=\mathrm{Me}_{3}: \mathrm{E}=\mathrm{S} \mathrm{4}$; Acenapyl = acenaphthylene-5,6-diyl) formed by metathetical methods from acenaphtho[5,6-cd]1,2-dichalcogenoles [AcenapylE 2 ( $(\mathbf{L} 1 \mathrm{E}=\mathrm{S}, \mathbf{L} 2 \mathrm{E}=\mathrm{Se})$ and cis- $\left[\mathrm{PtCl}_{2}\left(\mathrm{PR}_{3}\right)_{2}\right]\left(\mathrm{R}_{3}=\mathrm{Ph}_{3}, \mathrm{Ph}_{2} \mathrm{Me}, \mathrm{PhMe}_{2}, \mathrm{Me}_{3} ; \mathrm{Scheme}_{2}\right)$.

\section{Results and Discussion}

Platinum bis(phosphine) complexes 1-4 and 6-8 bearing acenaphtho[5,6-cd]-1,2-dichalcogenoles [AcenapylE $\left.{ }_{2}\right](\mathbf{L} \mathbf{E}=\mathrm{S}$, $\mathbf{L} 2 \mathrm{E}=\mathrm{Se})$ have been prepared by metathesis from cis- $\left[\mathrm{PtCl}_{2}\left(\mathrm{PR}_{3}\right)_{2}\right]\left(\mathrm{R}_{3}=\mathrm{Ph}_{3}, \mathrm{Ph}_{2} \mathrm{Me}, \mathrm{PhMe}_{2}, \mathrm{Me}_{3}\right)$ and the dilithium salts 
of the parent dichalcogen acenaphthylene ligands in 22-48\% yield. The platinum complex [Pt(COD)L1] (5) was also prepared from (1,5-cyclooctadiene)platinum(II) dichloride. Ligands $\mathbf{L 1}$ and $\mathbf{L} 2$ and complexes 1-3 and 5-8 were synthesised and fully characterised, principally by multinuclear magnetic resonance, IR spectroscopy and mass spectrometry. The homogeneity of the new compounds was, where possible, confirmed by microanalysis.

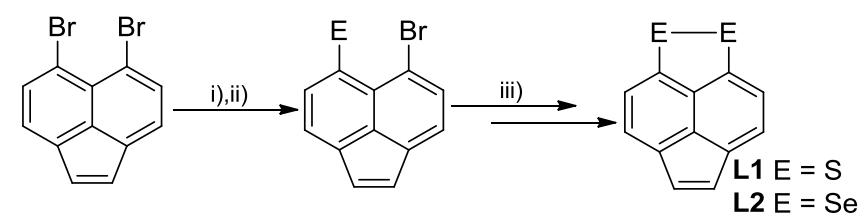

Scheme 1. Synthetic route to AcenapylS $\mathrm{S}_{2}$ (L1) and AcenapylSe ${ }_{2}$ (L2): i) $\mathrm{TMEDA}\left(2\right.$ eq.), $n \mathrm{BuLi}\left(1 \mathrm{eq}\right.$ ), $\mathrm{THF},-78^{\circ} \mathrm{C}, 30$ min; ii) E (1 eq.), THF, $-40{ }^{\circ} \mathrm{C}, 2$ h; iii) TMEDA (2 eq.), $n \operatorname{BuLi}\left(1\right.$ eq.), THF, $-78{ }^{\circ} \mathrm{C}, 30$ min then $\mathrm{E}$ ( 1 eq.), THF, $-40{ }^{\circ} \mathrm{C}$.

The ligands acenaphtho[5,6-cd]-1,2-dithiole (AcenapylS $\left.{ }_{2}, \mathbf{L 1}\right)$ and acenaphtho[5,6-cd]-1,2-diselenole (AcenapylSe ${ }_{2}$, L2) were prepared following a modification of the literature procedure (Scheme 1).[12] Two equivalents of TMEDA were added to a solution of 5,6-dibromoacenaphthylene[13] in diethyl ether at $-78{ }^{\circ} \mathrm{C}$. One equivalent of $n$ BuLi was added dropwise and the solution was left to stir for fifteen minutes. One equivalent of the appropriate chalcogen was added, the temperature was raised to $-40{ }^{\circ} \mathrm{C}$ and the reaction left to stir for two hours. A further one equivalent of $n \mathrm{BuLi}$ and chalcogen were added to replace the remaining bromine and then a further equivalent of chalcogen was added. After mild oxidation in air and purification the dichalcogen bridged ligands $\mathbf{L 1}$ and L2 were collected in yields of 5\% and 26\%, respectively. Attempts to improve these yields proved unsuccessful.

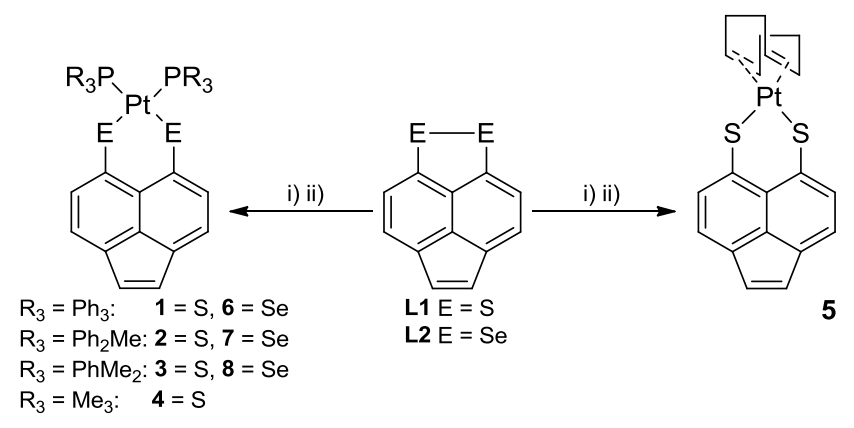

Scheme 2. Reaction route for the synthesis of the platinum (II) complexes $\left[\mathrm{Pt}\left(5,6-\mathrm{AcenapylE}_{2}\right)\left(\mathrm{PR}_{3}\right)_{2}\right] \mathbf{1 - 4}, \mathbf{6 - 8}$ and [Pt(COD)L1] 5: i) $\mathrm{LiBEt}_{3} \mathrm{H}$ (2 eq.), THF, r.t.; ii) $\left[\mathrm{PtCl}_{2}\left(\mathrm{PR}_{3}\right)_{2}\right] /\left[\mathrm{Pt}(\mathrm{COD}) \mathrm{Cl}_{2}\right]$, THF.

Synthesis of the platinum complexes followed a metathetical reaction that has been well documented in the preparation of similar complexes (Scheme 2).[9,10,11] The chalcogen-chalcogen bonds in $\mathbf{L} 1$ and $\mathbf{L} 2$ were reduced with two equivalents of lithium triethylborohydride in tetrahydrofuran at room temperature to form the dilithio-species. Metathetical addition of the dilithio-species to a suspension of the appropriate cis-dichlorobis(phosphine)platinum in tetrahydrofuran resulted in the formation of the platinum complexes $\left[\mathrm{Pt}\left(5,6-\mathrm{AcenapylE}_{2}\right)\left(\mathrm{PR}_{3}\right)_{2}\right]\left(\mathrm{R}_{3}=\mathrm{Ph}_{3}: \mathrm{E}=\mathrm{S} \mathrm{1}\right.$, Se 6; $\mathrm{R}_{3}=\mathrm{Ph}_{2} \mathrm{Me}: \mathrm{E}=\mathrm{S} \mathrm{2}, \mathrm{Se}$ 7; $\mathrm{R}_{3}=$ $\left.\mathrm{PhMe}_{2}: \mathrm{E}=\mathrm{S} \mathrm{3}, \mathrm{Se} \mathrm{8} ; \mathrm{R}_{3}=\mathrm{Me}_{3}: \mathrm{E}=\mathrm{S} 4\right) .{ }^{31} \mathrm{P}$ NMR stiudies of the cryde reaction mixtures showed only starting material and product resonances Unfortunately, despite changing conditions and several different attempts the yields were not improved and complex 4 was obtained in poor yield and only ${ }^{31}$ P NMR was acquired. The dilithio-species of L1 and L2 were also reacted with (1,5-cyclooctadiene)platinum(II) dichloride. This reaction was successful with L1 resulting in the platinum complex [Pt(5,6-AcenapylS 2$)(\mathrm{COD})]$ (5) (Scheme 2). 
Table 1. ${ }^{31} \mathrm{P}\left\{{ }^{1} \mathrm{H}\right\}$ NMR spectroscopic data for complexes 1-4, 6-8.

\begin{tabular}{|c|c|c|c|}
\hline & Chemical Shifts [ppm] & \multicolumn{2}{|c|}{ Coupling Constants $[\mathrm{Hz}]$} \\
\hline Product & $\delta\left({ }^{31} \mathrm{P}\right)$ & \multicolumn{2}{|c|}{${ }^{1} J\left({ }^{31} \mathrm{P}-{ }^{195} \mathrm{Pt}\right)$} \\
\hline 1 & 23.9 & \multicolumn{2}{|c|}{2953} \\
\hline 2 & 3.5 & \multicolumn{2}{|c|}{2880} \\
\hline 3 & -14.5 & \multicolumn{2}{|c|}{2819} \\
\hline 4 & -24.7 & \multicolumn{2}{|c|}{2768} \\
\hline & Chemical Shifts [ppm] & \multicolumn{2}{|c|}{ Coupling Constants $[\mathrm{Hz}]$} \\
\hline Product & $\delta\left({ }^{31} \mathrm{P}\right)$ & ${ }^{1} J\left({ }^{31} \mathrm{P}-{ }^{195} \mathrm{Pt}\right)$ & ${ }^{2} J\left({ }^{31} \mathrm{P}-{ }^{77} \mathrm{Se}\right)$ \\
\hline 6 & 20.2 & 3014 & 54 \\
\hline 7 & 0.6 & 2932 & 54 \\
\hline 8 & -17.6 & 2873 & 52 \\
\hline
\end{tabular}

${ }^{31} \mathrm{P}\left\{{ }^{1} \mathrm{H}\right\}$ NMR spectroscopic data for the series of bisphoshine complexes is displayed in Table 1. The spectra of complexes 1-4, bearing the sulfur ligand L1, display the expected single resonances with platinum satellites. As the alkyl groups on phosphorus are varied from $\mathrm{R}_{3}=\mathrm{Ph}_{3}$ to $\mathrm{R}_{3}=\mathrm{Me}_{3}$ the resonance peak moves to a lower chemical shift $[\mathbf{1} \delta=23.9$ ppm, ${ }^{1} J\left({ }^{31} \mathrm{P},{ }^{195} \mathrm{Pt}\right)=2953 \mathrm{~Hz} ; 2 \delta=3.5 \mathrm{ppm},{ }^{1} J\left({ }^{31} \mathrm{P},{ }^{195} \mathrm{Pt}\right)=2880 \mathrm{~Hz} ; \mathbf{3} \delta=-14.5 \mathrm{ppm}{ }^{1} J\left({ }^{31} \mathrm{P},{ }^{195} \mathrm{Pt}\right)=2819 \mathrm{~Hz} ; \mathbf{4} \delta=-24.7$ ppm, ${ }^{1} J\left({ }^{31} \mathrm{P},{ }^{195} \mathrm{Pt}\right)=2768 \mathrm{~Hz}$ ], this trend was also observed in the analogous acenaphthene compounds.[11] Previously it has been observed that higher ${ }^{1} J\left({ }^{31} \mathrm{P}_{-}{ }^{195} \mathrm{Pt}\right)$ coupling constants exist for more electron withdrawing $\mathrm{R}$ groups, with ${ }^{1} J\left({ }^{31} \mathrm{P}-{ }^{195} \mathrm{Pt}\right)$ decreasing as phenyl groups are replaced with electron donating methyl groups.[10,11] It can be seen for 1-4 that there is a steady decrease in value for ${ }^{1} J\left({ }^{31} \mathrm{P}_{-}{ }^{195} \mathrm{Pt}\right)$ coupling as phenyl groups are replaced by more electron donating methyl groups. An equivalent trend is observed in the corresponding ${ }^{31} \mathrm{P}\left\{{ }^{1} \mathrm{H}\right\}$ NMR spectra of complexes 6-8, which similarly display single resonances with platinum satellites at $6 \delta\left({ }^{31} \mathrm{P}\right)=20.2 \mathrm{ppm}\left({ }^{1} J\left({ }^{31} \mathrm{P},{ }^{125} \mathrm{Pt}\right)=3014 \mathrm{~Hz}\right), 7 \delta\left({ }^{31} \mathrm{P}\right)=0.60 \mathrm{ppm}\left({ }^{1} J\left({ }^{31} \mathrm{P},{ }^{125} \mathrm{Pt}\right)=2932\right.$ $\mathrm{Hz})$ and $8 \delta\left({ }^{31} \mathrm{P}\right)=-17.6 \mathrm{ppm}\left({ }^{1} J\left({ }^{31} \mathrm{P},{ }^{125} \mathrm{Pt}\right)=2873 \mathrm{~Hz}\right)$ respectively, but with additional satellites attributed to ${ }^{31} \mathrm{P}-{ }^{77} \mathrm{Se}$ coupling $\left({ }^{2} J\left({ }^{31} \mathrm{P},{ }^{77} \mathrm{Se}\right)=654 \mathrm{~Hz}, 754 \mathrm{~Hz}, 852 \mathrm{~Hz}\right)$. The same pattern was observed in the ${ }^{31} \mathrm{P}\left\{{ }^{1} \mathrm{H}\right\} \mathrm{NMR}$ spectrum of analogous naphthalene complex $\left[\mathrm{Pt}\left(\mathrm{NapSe}_{2}\right)\left(\mathrm{PPh}_{3}\right)_{2}\right]\left(\delta\left({ }^{31} \mathrm{P}\right)=20.5 \mathrm{ppm}\left({ }^{1} J\left({ }^{31} \mathrm{P},{ }^{125} \mathrm{Pt}\right)=3016 \mathrm{~Hz},{ }^{2} J\left({ }^{31} \mathrm{P},{ }^{77} \mathrm{Se}\right)=51 \mathrm{~Hz}\right) \cdot[10]\right.$

In symmetrical systems such as these, the presence of the NMR-inactive isotopomer at the second Se coordination site causes the two ${ }^{31} \mathrm{P}$ environments to become magnetically inequivalent due to the resulting break in symmetry of the molecule. Consequently, each ${ }^{31} \mathrm{P}$ atom can align either cis or trans to the low abundance ${ }^{77}$ Se NMR active isotope $(7.6 \%),[14]$ which can result in two distinct, but comparable ${ }^{31} \mathrm{P}_{-}{ }^{77}$ Se coupling values. This secondary isotopomer effect was observed in the spectra of previously reported naphthalene $\left[\mathrm{Pt}\left(\mathrm{NapSe}_{2}\right)\left(\mathrm{PMe}_{3}\right)_{2}\right]$ and acenaphthene $\left[\mathrm{Pt}\left(\right.\right.$ AcenapSe $\left.\left._{2}\right)\left(\mathrm{PPhMe}_{2}\right)_{2}\right]$ platinum complexes with ${ }^{2} J_{\mathrm{PSe}}$ coupling observed for both the cis $(47 \mathrm{~Hz}, 47 \mathrm{~Hz})$ and trans $(53$ $\mathrm{Hz}, 56 \mathrm{~Hz}$ ) configurations in each case (Figure 2).[10,11] The absence of two distinct sets of satellites for cis/trans ${ }^{2} J\left({ }^{31} \mathrm{P},{ }^{77} \mathrm{Se}\right)$ coupling in the ${ }^{31} \mathrm{P}\left\{{ }^{1} \mathrm{H}\right\}$ NMR spectra of complexes 6-8 suggests the coupling constants are of a similar magnitude, and the individual satellites overlap; this is confirmed by measuring integral peak intensities $\left({ }^{31} \mathrm{P}:{ }^{77} \mathrm{Se}\right)$. In addition, ${ }^{1} J\left({ }^{31} \mathrm{P},{ }^{31} \mathrm{P}\right)$ coupling constants are notoriously small in such AA'X spin systems[15] and as such are also not observed in ${ }^{31} \mathrm{P}\left\{{ }^{1} \mathrm{H}\right\}$ NMR spectra of complexes 6-8. 


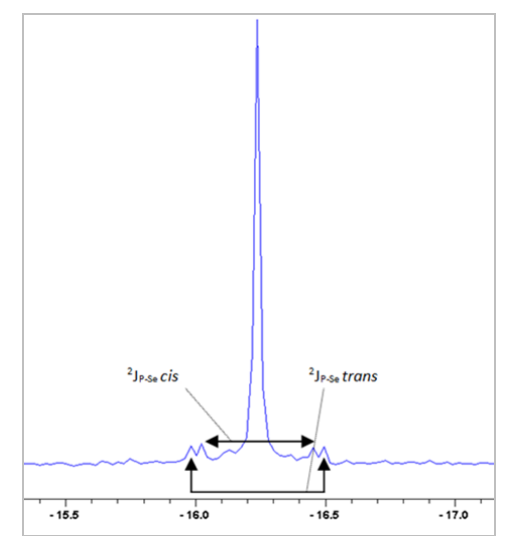

Figure 2. ${ }^{31} \mathrm{P}\left\{{ }^{1} \mathrm{H}\right\}$ NMR spectrum for $\left[\mathrm{Pt}\left(\mathrm{AcenapSe}_{2}\right)\left(\mathrm{PPhMe}_{2}\right)_{2}\right]$ showing the cis and trans satellites with ${ }^{2} J_{\mathrm{PSe}}$ coupling.[11]

Unsurprisingly, secondary isotopomer effects are also observed in the ${ }^{77} \mathrm{Se}$ NMR spectra of 6-8 which display complex satellite systems due to cis/trans ${ }^{2} J\left({ }^{77} \mathrm{Se},{ }^{31} \mathrm{P}\right)$ coupling and ${ }^{1} J\left({ }^{77} \mathrm{Se},{ }^{195} \mathrm{Pt}\right)$ coupling. The spectra of complexes 6 and 7 are poorly resolved and appear as approximate 'septets' centred at $\delta\left({ }^{77} \mathrm{Se}\right)=228 \mathrm{ppm}$ and $\delta\left({ }^{77} \mathrm{Se}\right)=204 \mathrm{ppm}$, respectively. The ${ }^{77} \mathrm{Se}$ NMR resonance of complex $\mathbf{8}$, meanwhile, appears as an overlapping second-order doublet of doublets centred at $\delta\left({ }^{77} \mathrm{Se}\right)=174.6 \mathrm{ppm}$, with cis and trans ${ }^{2} J\left({ }^{77} \mathrm{Se},{ }^{31} \mathrm{P}\right)$ coupling $\approx 52 \mathrm{~Hz}$ and reciprocal satellites for ${ }^{1} \mathrm{~J}\left({ }^{77} \mathrm{Se},{ }^{195} \mathrm{Pt}\right)$ coupling $(251$ $\mathrm{Hz}$; Figure 3). The values seen for the ${ }^{1} J_{\text {SePt }}$ satellites are similar to those observed by other groups.[16]

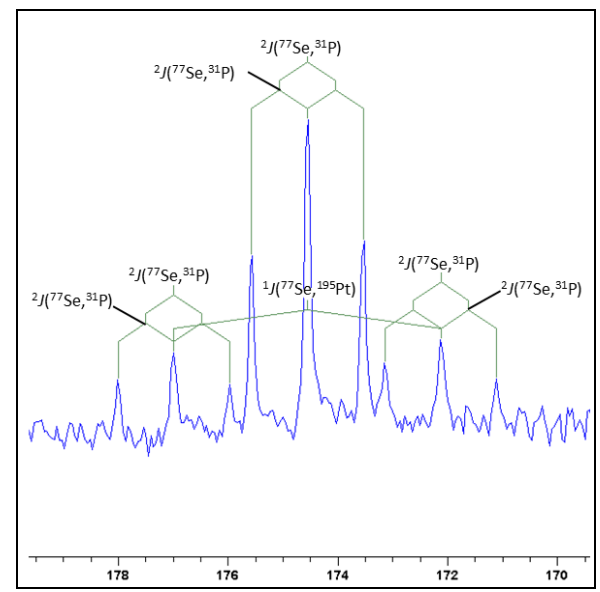

Figure 3. ${ }^{77}$ Se NMR spectrum for complex 8 displaying the overlapping second-order doublet of doublets and corresponding ${ }^{195} \mathrm{Pt}$ satellites.

As previously discussed, a steady decrease in magnitude is observed in the ${ }^{1} J\left({ }^{31} \mathrm{P}-{ }^{195} \mathrm{Pt}\right)$ coupling constant as the phenyl groups are replaced by methyl groups (Table 1). In contrast, a steady increase in magnitude is observed in the ${ }^{1} J\left({ }^{77} \mathrm{Se}-{ }^{195} \mathrm{Pt}\right)$ coupling constant. These opposing trends are due to a combination of factors. A decrease in electronegativity of the alkyl groups occurs each time a phenyl is replaced by a methyl. The platinum centre becomes more electron rich as a consequence of the alkyl groups becoming more electropositive, this causes a decrease in the $s$-character of the P-Pt bond. This implies the lone pair on the phosphorus is less tightly bound and subsequently strengthens the P-Pt bond. The $s$-character of the P-Pt 
bond decreases because the platinum becomes more electron rich as methyl groups are added, in turn the P-C $\mathrm{C}_{\mathrm{R}}$ bond adopts more $s$-character to stabilise the local negative charge.[17]

In addition, the increase in ${ }^{1} J\left({ }^{77} \mathrm{Se}-{ }^{195} \mathrm{Pt}\right)$ coupling constants can be partially attributed to phenyl groups being greater $\pi$ acceptors than methyl groups. When $\pi$-acceptors are in the trans position they reduce the magnitude of the coupling constant between the metal and the ligand i.e. platinum and selenium. As phenyl is replaced with the poorer $\pi$-acceptor methyl the coupling constant increases. However, the trans influence is not fully responsible for the increase we observe in coupling constant, the $s$-character in the Pt-Se bond and the subsequent $s$-electron density at the platinum centre is also responsible.[17]

Table 2. Selected interatomic distances $[\AA]$ and angles $\left[{ }^{\circ}\right]$ for $\mathbf{L 1}, \mathbf{1}, \mathbf{3}, \mathbf{6}$.

\begin{tabular}{|c|c|c|c|c|}
\hline Compound & L1 & 1 & 3 & 6 \\
\hline Ligand; peri-atoms & SS & L1; SS & L1; SS & L2, SeSe \\
\hline $\mathrm{E}(1) \cdots \mathrm{E}(2)$ & $2.084(2)$ & $3.343(3)$ & $3.431(11)$ & $3.452(4)$ \\
\hline$\Sigma \mathrm{r}_{\mathrm{vdW}}-\mathrm{E}(1) \cdots \mathrm{E}(2)^{\mathrm{a}} ; \% \Sigma \mathrm{r}_{\mathrm{vdW}}{ }^{[\mathrm{a}]}$ & $1.516 ; 58$ & $0.257 ; 93$ & $0.169 ; 95$ & $0.348 ; 91$ \\
\hline \multicolumn{5}{|l|}{ Peri-region bond angles } \\
\hline $\mathrm{E}(1)-\mathrm{C}(1)-\mathrm{C}(10)$ & $113.88(16)$ & $124.6(6)$ & $127(3)$ & $127.8(7)$ \\
\hline $\mathrm{C}(1)-\mathrm{C}(10)-\mathrm{C}(9)$ & $118.78(16)$ & $128.8(7)$ & $131(3)$ & $131.0(8)$ \\
\hline $\mathrm{E}(2)-\mathrm{C}(9)-\mathrm{C}(10)$ & $115.66(16)$ & $127.1(6)$ & $128(2)$ & $127.4(7)$ \\
\hline$\Sigma$ of bay angles & $348.32(28)$ & $380.5(11)$ & $386(5)$ & $386.2(13)$ \\
\hline Splay angle ${ }^{[b]}$ & -11.7 & 20.5 & 26.0 & 26.2 \\
\hline \multicolumn{5}{|l|}{ Out-of-plane displacement } \\
\hline $\mathrm{E}(1)$ & $0.090(1)$ & $-0.525(1)$ & $-0.009(1)$ & $0.012(1)$ \\
\hline $\mathrm{E}(2)$ & $0.020(1)$ & $0.449(1)$ & $0.105(1)$ & $-0.019(1)$ \\
\hline \multicolumn{5}{|c|}{ Central naphthalene ring torsion angles } \\
\hline $\mathrm{C}:(6)-(5)-(10)-(1)$ & $178.12(15)$ & $-172.7(7)$ & $179(3)$ & $-179.2(9)$ \\
\hline C:(4)-(5)-(10)-(9) & $-177.80(16)$ & $-177.7(7)$ & $-174(3)$ & 178.7(9) \\
\hline
\end{tabular}

[a] van der Waals radii used for calculations: $\mathrm{r}_{\mathrm{vdW}}(\mathrm{S}) 1.80 \AA$, $\mathrm{r}_{\mathrm{vdW}}(\mathrm{Se}) 1.90 \AA$ [4]]; [b] Splay angle: $\Sigma$ of the three bay region angles -360 . 
X-ray Investigations: Single crystals were obtained for $\mathbf{L} \mathbf{1}$ by cooling a hot hexane solution to $-35{ }^{\circ} \mathrm{C}$ overnight. The molecular structure of $\mathbf{L 1}$ is shown in Figure 5. Although $\mathbf{L 1}$ is a known compound with published characterisation data,[12] no crystal data have been published. The crystal structure of L1 has a peri sulfur-sulfur bond distance of 2.084(2) $\AA$. This is much shorter than the peri-distance in unsubstituted acenaphthylene of $c a$. $2.73 \AA$,[3] this is expected as a bond has formed between the peri-substituents. However, the S-S bond does fall within the 'normal' length for a compound of this type with typical values of $c a$. $2.05 \AA$ being reported.[18] The peri-angles in acenaphthylene are $120.3(8)^{\circ}, 127.8(6)^{\circ}$ and $120.3(8)^{\circ}$ with the sum being $368.4^{\circ}$. [3] In $\mathbf{~} \mathbf{1}$ the sum of the bay angles is $348.32(28)^{\circ}$ with a resulting negative splay angle of $-11.7^{\circ}$; this is less than the sum in ideal acenaphthylene confirming a favourable interaction is occurring between the peri-atoms resulting in the formation of a peri-bond. Minor out-ofplane distortion is observed with both sulfur atoms sitting 0.02(1) $\AA$ and 0.09(1) $\AA$ away from the naphthyl plane. This is accompanied by a minor distortion to the geometry of the 'naphthalene' framework with $\mathrm{C}-\mathrm{C}$-C-C torsion angles deviating by $1.88^{\circ}$ and $2.20^{\circ}$ from the 'ideal' $180^{\circ}$.

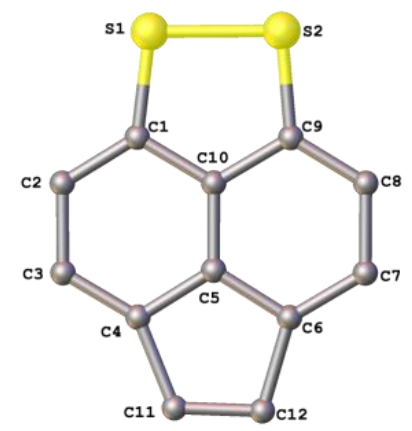

Figure 5. The molecular structure of $\mathbf{L} \mathbf{1}$ with $\mathrm{H}$ atoms omitted for clarity.

It is not surprising that $\mathbf{L 1}$ displays similar characteristics to naphtha[1,8-cd][1,2]dithiole $\left[\mathrm{NapS}_{2}\right][10]$ and 5,6dihydroacenaphtho[5,6-cd]-1,2-dithiole [AcenapS $S_{2}$ ].[11] The peri-distances observed in all three compounds are statistically equivalent with values of 2.0879(8) $\AA$,[10] 2.1025(19) $\AA$ [11] and 2.084(2) $\AA$ for $\mathrm{NapS}_{2}, \mathrm{AcenapS}_{2}$ and $\mathbf{L 1}$,

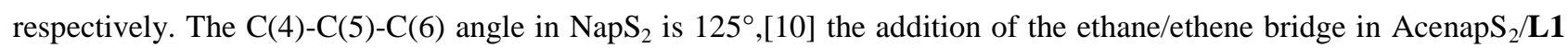
causes compression of this angle, with values of $114.9(5)^{\circ}[11]$ and $116.30(16)^{\circ}$, respectively. One would expect compression of the $\mathrm{C}(4)-\mathrm{C}(5)-\mathrm{C}(6)$ angle to cause an expansion in the $\mathrm{C}(1)-\mathrm{C}(10)-\mathrm{C}(9)$ angle however, this is not strictly the case. An increase in the $\mathrm{C}(1)-\mathrm{C}(10)-\mathrm{C}(9)$ angle is seen between $\mathrm{NapS}_{2}$ and $\mathrm{AcenapS}_{2}\left(118.65(16)^{\circ}\right.$ to $\left.120.2(5)^{\circ}\right),[10,11]$ but a decrease then occurs with $\mathbf{L 1}$ having a $\mathrm{C}(1)-\mathrm{C}(10)-\mathrm{C}(9)$ angle of $118.78(16)^{\circ}$. This is reflected in the splay angles with values of $-11.2^{\circ},[10]-11.8^{\circ}[11]$ and $-11.7^{\circ}$ for $\mathrm{NapS}_{2}$, AcenapS $\mathrm{S}_{2}$ and $\mathbf{L 1}$, respectively. All three ligands have similar out-of-plane displacement with the sulfur atoms sitting ca. $0.02 \AA$ from the naphthyl plane. L1 has the largest, although still minor, naphthalene framework distortion with C-C-C-C torsion angles deviating from $180^{\circ}$ by $1.88^{\circ}$ and $2.20^{\circ}\left(c f . \mathrm{NapS}_{2}\right.$ and $\left.\mathrm{AcenapS}_{2} c a .0 .40^{\circ}\right) .[10,11]$

Single crystals were obtained for $\mathbf{1}$ by evaporation of a saturated solution of the compound in chloroform. $\mathbf{1}$ crystallises with two dichloromethane molecules per platinum molecule. Single crystals of $\mathbf{3}$ and $\mathbf{6}$ were obtained by diffusion of hexane into a saturated solution of the compound in diethyl ether. The molecular structures of 1, 3 and 6 are shown in Figures 6 and 10, respectively. 

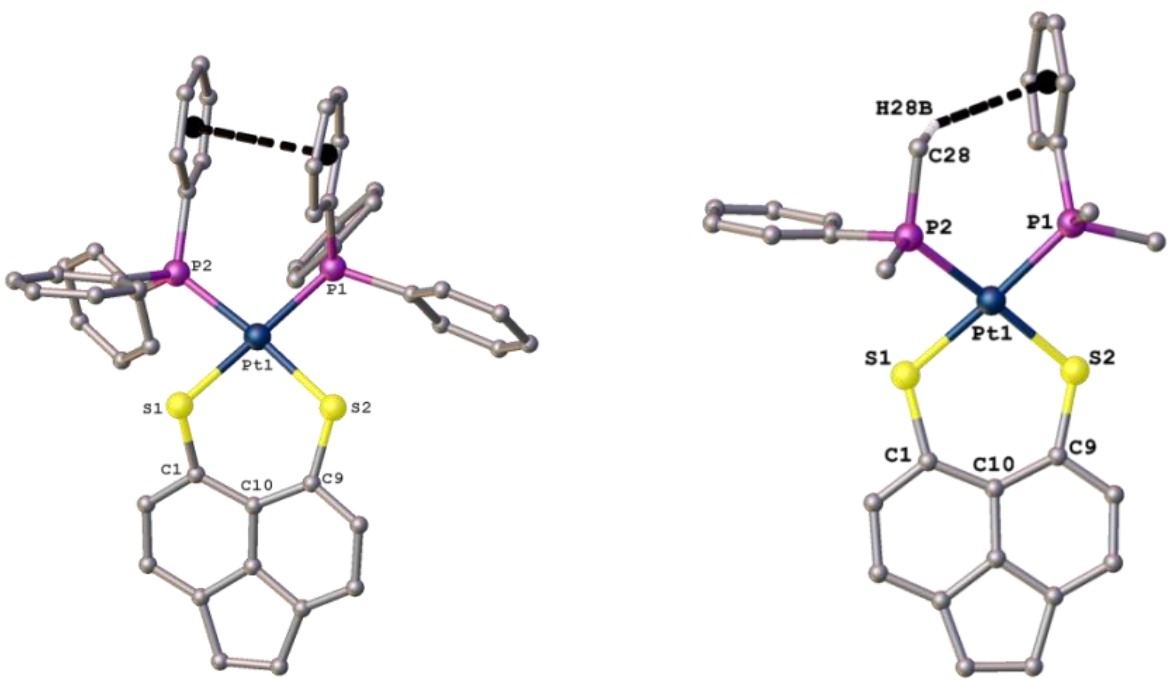

Figure 6. The molecular structures of $\mathbf{1}$ and $\mathbf{3}$, showing the weak intramolecular interactions; solvent molecules and $\mathrm{H}$ atoms omitted for clarity.

Table 3. Platinum coordination geometry; selected intramolecular distances $[\AA]$ and angles $\left[{ }^{\circ}\right]$ for $\mathbf{1}, \mathbf{3}$, and $\mathbf{6}$.

\begin{tabular}{llll}
\hline Complex & $\mathbf{1}$ & $\mathbf{3}$ & $\mathbf{6}$ \\
\hline Ligand; peri-atoms & L1; SS & L1, SS & L2, SeSe \\
Metal geometry - bond lengths & & & $2.432(2)$ \\
$\mathrm{E}(1)-\mathrm{Pt}(1)$ & $2.326(2)$ & $2.334(9)$ & $2.4449(19)$ \\
$\mathrm{E}(2)-\mathrm{Pt}(1)$ & $2.3212(19)$ & $2.315(8)$ & $2.305(3)$ \\
$\mathrm{P}(1)-\mathrm{Pt}(1)$ & $2.289(2)$ & $2.293(9)$ & $2.290(3)$ \\
$\mathrm{P}(2)-\mathrm{Pt}(1)$ & $2.2991(19)$ & $2.293(9)$ & $90.12(8)$ \\
Metal geometry-bond angles & & & $96.98(11)$ \\
$\mathrm{E}(1)-\mathrm{Pt}(1)-\mathrm{E}(2)$ & $92.07(7)$ & $95.1(3)$ & $86.97(10)$ \\
$\mathrm{P}(1)-\mathrm{Pt}(1)-\mathrm{P}(2)$ & $96.08(7)$ & $93.6(3)$ & $86.93(10)$ \\
$\mathrm{E}(1)-\mathrm{Pt}(1)-\mathrm{P}(2)$ & $82.96(7)$ & $83.9(3)$ & $142.98(1)$ \\
$\mathrm{E}(2)-\mathrm{Pt}(1)-\mathrm{P}(1)$ & $88.94(7)$ & $87.5(3)$ & $1.037(1)$ \\
Envelope geometry & & & $154.79(1)$ \\
$\mathrm{E} \mathrm{E}_{2}-\mathrm{Pt}$ angle & $144.13(1)$ & $0.576(1)$ & \\
$\mathrm{E}_{2} \mathrm{C}_{3}-\mathrm{Pt}$ distance & $0.937(1)$ & & \\
\hline
\end{tabular}

In the three complexes, the dichalcogenate acenaphthylene acts as a bidentate ligand, coordinating to the platinum via the two chalcogen atoms to form a six-membered $\mathrm{PtC}_{3} \mathrm{E}_{2}$ chelate ring. A distorted square planar geometry is adopted by the platinum centre in each case, with angles deviating from the ideal $\left(90^{\circ}\right)$. As expected the peri-distances in $\mathbf{1}$ and $\mathbf{3}$ have been elongated due to the breaking of the sulfur-sulfur bond and insertion of the platinum. The non-bonded sulfursulfur distance being 3.343(3) $\AA$ for 1 and 3.431(11) $\AA$ for 3 compared to the bonded distance of 2.084(2) $\AA$ in the free ligand L1. However, the peri-distance in the two complexes is still shorter than the sum of the van der Waals radii for two sulfur atoms by $5-7 \%$. The angles of the bay region increase as a consequence of the increase in peri-distance, with positive splay angles of $20.5^{\circ}$ and $26.0^{\circ}$ being seen for $\mathbf{1}$ and $\mathbf{3}$ respectively. This is significantly greater than the negative splay angle of $-11.7^{\circ}$ that is observed in $\mathbf{L 1}$ due to the presence of the sulfur-sulfur bridge. 
1 displays much greater distortion of the naphthalene skeleton than $\mathbf{3}$. The non-bonded peri-distance and the splay angle in $\mathbf{3}$ are larger than those in $\mathbf{1}$ creating a more relaxed geometry around the platinum centre which can accommodate the dimethyl-phenylphosphine groups without causing great distortion to the naphthalene backbone. In L1 the sulfur atoms lie 0.09(1) $\AA$ and 0.02(1) $\AA$ above the naphthyl plane. 1 displays significant out-of-plane distortion in comparison to the ligand; one sulfur atom sits 0.525(1) $\AA$ below the naphthyl plane and the other sits $0.449(1) \AA$ above the plane. 3 shows less out-of-plane distortion than 1, with one sulfur atom lying 0.105(1) $\AA$ above the naphthyl plane and the other lying on the plane. The torsion angles also deviate from the free ligand by $c a .1-7.3^{\circ}$ with 1 showing the greatest buckling of the naphthalene carbon framework. Greater distortion is observed in $\mathbf{1}$ due to the bulky triphenylphosphine groups making it more difficult for the complex to maintain a square planar environment around the platinum centre when compared to the smaller dimethylphenylphosphine groups.

Changing the alkyl groups from triphenylphosphines to dimethylphenylphosphines has a minor effect on the geometry of the corresponding acenaphthene complexes, $\left[\operatorname{Pt}(\operatorname{AcenapS})_{2}\left(\mathrm{PPh}_{3}\right)_{2}\right]$ and $\left[\operatorname{Pt}(\operatorname{AcenapS})_{2}\left(\mathrm{PPhMe}_{2}\right)_{2}\right]$.[11] Unfortunately a comparison with the equivalent naphthalene complexes is not possible, as $\left[\mathrm{Pt}\left(\mathrm{NapS}_{2}\right)\left(\mathrm{PPh}_{3}\right)_{2}\right]$ could not be crystallised and $\left[\mathrm{Pt}\left(\mathrm{NapS}_{2}\right)\left(\mathrm{PPhMe}_{2}\right)_{2}\right]$ has not been prepared.[10]

In 1 a weak $\pi \cdots \pi$ interaction is observed with two phenyl rings, one from each $\mathrm{PPh}_{3}$ group, adopting a face-to-face alignment (Figure 6) with a $\mathrm{Cg}(\mathrm{C} 13-\mathrm{C} 18) \cdots \mathrm{Cg}(\mathrm{C} 31-\mathrm{C} 36)$ distance of 3.620(1) $\AA$. This value is comparable with that found in the acenaphthene complex $\left[\mathrm{Pt}\left(\mathrm{AcenapS}_{2}\right)\left(\mathrm{Pt}\left(\mathrm{PPh}_{3}\right)_{2}\right]\right.$ which has a $\mathrm{Cg}(\mathrm{C} 25-\mathrm{C} 30) \cdots \mathrm{Cg}(\mathrm{C} 31-\mathrm{C} 36)$ distance of 3.765(1) A.[11] However, in 3 the intramolecular interaction observed is a C-H $\cdots \pi$ interaction, it is now a phenyl ring from one $\mathrm{PPh}_{2} \mathrm{Me}$ group that is interacting with a methyl group from the other $\mathrm{PPh}_{2} \mathrm{Me}$ group (Figure 6), giving a C28$\mathrm{H} 28 \mathrm{~B} \cdots \mathrm{Cg}(\mathrm{C} 13-\mathrm{C} 18)$ distance of $2.847(1) \AA$. Again, this value is comparable with $\left[\mathrm{Pt}\left(\mathrm{AcenapS}_{2}\right)\left(\mathrm{PPhMe}_{2}\right)_{2}\right]$ which

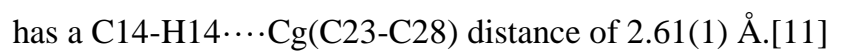

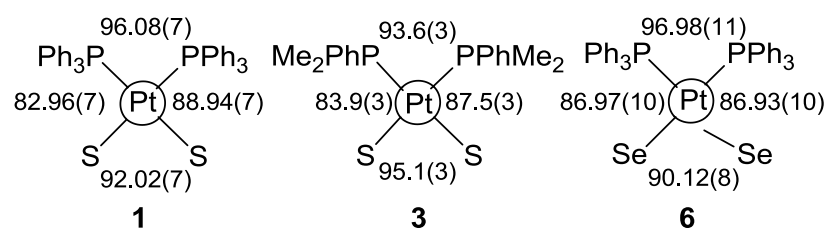

Figure 7. Comparison of the angles $\left(^{\circ}\right)$ associated with the square planar geometry of the platinum metal in complexes $\mathbf{1 ,} 3$ and $\mathbf{6}$.

The platinum metal centre in $\mathbf{1}$ and $\mathbf{3}$ maintains a distorted square planar geometry (Figure 7). The $\mathrm{P}(1)-\mathrm{Pt}(1)-\mathrm{P}(2)$ angle of $96.08(7)^{\circ}$ for $\mathbf{1}$ is larger than the $\mathrm{P}(1)-\mathrm{Pt}(1)-\mathrm{P}(2)$ angle of $93.6(3)^{\circ}$ in 3 . This angle is larger in $\mathbf{1}$ in order to accommodate the bulky triphenylphosphine groups; replacement of two phenyl groups with the less sterically demanding methyl groups allows reduction of this angle to occur in 3. One would expect the $S(1)-\operatorname{Pt}(1)-P(2)$ and $S(2)-$ $\operatorname{Pt}(1)-\mathrm{P}(1)$ angles to be equal, however this is not the case. This is a consequence of the distortion in the naphthalene framework. The $\mathrm{P}(1)-\mathrm{Pt}(1)-\mathrm{P}(2)$ angle in $\mathbf{1}$ is smaller than that in $\mathbf{3}\left(92.02(7)^{\circ}\right.$ and $\left.95.1(3)^{\circ}\right)$ this is expected as the peridistance and splay angle observed in $\mathbf{3}$ is more relaxed than those in $\mathbf{1}$. No significant differences in the Pt bond lengths are observed between the complexes. 
In $\mathbf{1}$ and 3, $\mathbf{L 1}$ acts as a bidentate ligand, coordinating to the platinum via the chalcogen atoms to form a six-membered chelate ring. This six-membered $\mathrm{PtS}_{2} \mathrm{C}_{3}$ ring can be described as having a twisted envelope type conformation with the $\mathrm{S} \cdots \mathrm{S}$ vector as the hinge (Figure 8). In $1 \mathrm{C}(1), \mathrm{C}(10)$ and $\mathrm{C}(9)$ all lie in a plane with $\mathrm{S}(1)$ lying $0.525(1) \AA$ below the plane and S(2) lying 0.449(1) $\AA$ above the plane. This results in a non-planar, twisted $\mathrm{PtS}_{2} \mathrm{C}_{3}$ ring. In 3 the $\mathrm{PtS}_{2} \mathrm{C}_{3}$ ring is closer to planar with the sulfur atoms deviating from the plane by 0.009(1) $\AA$ and 0.105(1) $\AA$. The mean plane of $\mathrm{S}(1), \mathrm{S}(2), \mathrm{C}(1), \mathrm{C}(10)$ and $\mathrm{C}(9)$ and the displacement of $\mathrm{Pt}(1)$, which sits in the peri-gap above the plane, is measured. In 1 the $\mathrm{Pt}(1)$ sits $0.937(1) \AA$ above the mean plane and the angle of the $\mathrm{S}(1) \cdots \mathrm{S}(2)$ hinge is $144.13(1)^{\circ}$. Whereas in 3 the $\operatorname{Pt}(1)$ sits $0.576(1) \AA$ above the mean plane and the $S(1) \cdots S(2)$ hinge angle is $154.79(1)^{\circ}$. The larger angle and in turn shorter $\mathrm{Pt}(1)$ displacement observed for $\mathbf{3}$ is expected due to this complex displaying less distortion than $\mathbf{1}$.

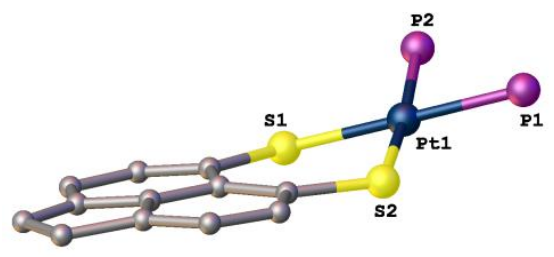

Figure 8. The twisted envelope configuration of the 6-membered chelate ring, formed from bidentate $\mathrm{S}$ coordination of $\mathbf{L 1}$ in complex $\mathbf{3}$ (phenyl and methyl groups and $\mathrm{H}$ atoms omitted for clarity).

The non-bonded peri-distance in $\mathbf{1}$ of 3.343(3) $\AA$ is shorter than that of 3.452(4) $\AA$ in $\mathbf{6}$. This is expected due to the van der Waals radius of sulfur being smaller than that of selenium (1.80 ̊ vs. $1.90 \AA$ ).[4] The peri-distance observed in both complexes is shorter than the sum of their respective van der Waals radii by 7-9\%. As expected, breaking of the chalcogen-chalcogen peri-bond and insertion of the platinum results in a positive splay angle being observed in both complexes with 6 having a larger splay angle than $\mathbf{1}\left(26.2^{\circ}\right.$ and $\left.20.5^{\circ}\right)$. Significant out-of-plane distortion is observed in 1 with one sulfur atom lying 0.525(1) A below the acenaphthylene plane and the other lying 0.449(1) $\AA$ above the plane (Figure 9). This is accompanied by distortion of the acenaphthylene ring with torsion angles deviating from the ideal $180^{\circ}$ by $2.3-7.2^{\circ}$. In comparison, 6 shows much less distortion with the selenium atoms lying $0.012(1) \AA$ and $0.019(1)$ $\AA$ above and below the acenaphthylene plane (Figure 9). The acenaphthylene ring shows little buckling with torsion angles varying from $180^{\circ}$ by $0.8-1.3^{\circ}$. Similar trends in peri-distance and splay angle are seen between $\left[\mathrm{Pt}\left(\mathrm{AcenapS}_{2}\right)\left(\mathrm{PPh}_{3}\right)_{2}\right]$ and $\left.\left[\mathrm{Pt}(\mathrm{AcenapSe})_{2}\right)\left(\mathrm{PPh}_{3}\right)_{2}\right]$. However, differences are observed in out-of-plane distortion and torsion angles with both acenaphthene complexes having similar values and therefore similar levels of distortion.[11]

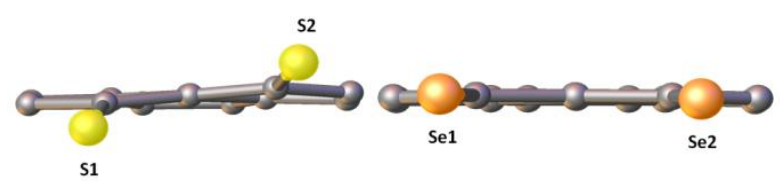

Figure 9. Comparison of the out-of-plane distortion and naphthalene ring deformation seen in $\mathbf{1}$ and $\mathbf{6}$, other atoms have been omitted for clarity.

In 1 two phenyl rings, one from each of the two $\mathrm{PPh}_{3}$ groups, adopt a face-to-face alignment leading to a weak $\pi \cdots \pi$ interaction (Figure 6) with a $\mathrm{Cg}(\mathrm{C} 13-\mathrm{C} 18) \cdots \mathrm{Cg}(\mathrm{C} 31-\mathrm{C} 36)$ distance of 3.620(1) $\AA$. 6 also shows a weak $\pi \cdots \pi$ interaction (Figure 10) with a $\mathrm{Cg}(\mathrm{C} 13-\mathrm{C} 18) \cdots \mathrm{Cg}(\mathrm{C} 37-\mathrm{C} 42)$ distance of 3.801(1) $\AA$. These values are comparable with those seen in $\left[\operatorname{Pt}\left(\mathrm{AcenapS}_{2}\right)\left(\mathrm{PPh}_{3}\right)_{2}\right](3.765(1) \AA)$ and $\left[\mathrm{Pt}\left(\mathrm{AcenapSe}_{2}\right)\left(\mathrm{PPh}_{3}\right)_{2}\right](3.764(1) \AA) .[11]$ 


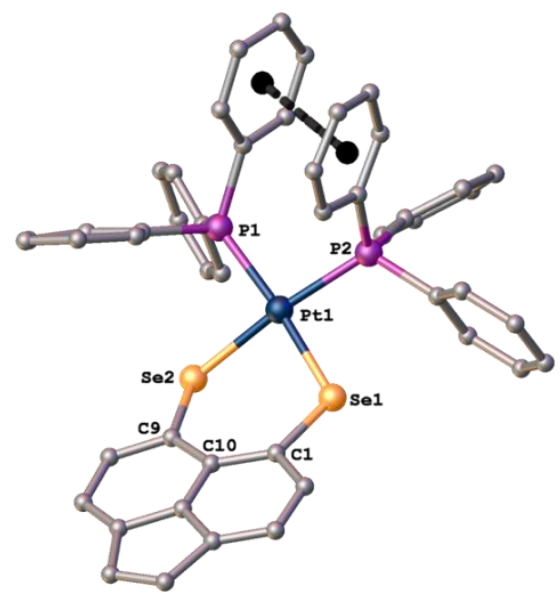

Figure 10. The molecular structures of 6 , showing the weak $\pi \cdots \pi$ interaction with $\mathrm{H}$ atoms omitted for clarity.

In 1 and 6 the platinum metal centre adopts a distorted square planar geometry (Figure 7). The $\mathrm{P}(1)-\mathrm{Pt}(1)-\mathrm{P}(2)$ angle of $96.08(7)^{\circ}$ and $96.98(11)^{\circ}$ for $\mathbf{1}$ and $\mathbf{6}$, respectively is larger than the ideal $90^{\circ}$ in order to accommodate the bulky triphenylphosphine groups. The E-Pt-P angles observed in both complexes are smaller than $90^{\circ}$, the expansion of the $\mathrm{P}(1)-\mathrm{Pt}(1)-\mathrm{P}(2)$ angle causes compression of these angles due to the restriction imposed by the peri-geometry which fixes the sulfur and selenium atoms. The $\mathrm{Se}(1)-\mathrm{Pt}(1)-\mathrm{P}(2)$ and $\mathrm{Se}(2)-\mathrm{Pt}(1)-\mathrm{P}(1)$ angles of $86.97(10)^{\circ}$ and $86.93(10)^{\circ}$ are equal. In comparison the $\mathrm{S}(1)-\mathrm{Pt}(1)-\mathrm{P}(2)$ angle of $82.96(7)^{\circ}$ is much smaller than the $\mathrm{S}(2)-\mathrm{Pt}(1)-\mathrm{P}(1)$ angle of $88.94(7)^{\circ}$, this is due to the large out-of-plane distortion of the sulfur atoms causing twisting in the $\mathrm{PtS}_{2} \mathrm{C}_{3}$ ring. The $\mathrm{S}(1)-\mathrm{Pt}(1)$ $\mathrm{S}(2)$ angle of $92.02(7)^{\circ}$ is larger than the $\mathrm{Se}(1)-\mathrm{Pt}(1)-\mathrm{Se}(2)$ of $90.12(8)^{\circ}$. One would expect the $\mathrm{S}(1)-\mathrm{Pt}(1)-\mathrm{S}(2)$ to be the smaller angle as the non-bonded peri-distance observed in 1 is smaller than that of 6 (3.343(3) $\AA$ and $3.452(4) \AA$, respectively). However, the out-of-plane distortion in $\mathbf{1}$ is much greater than that in $\mathbf{6}$, as a consequence of this the most comfortable position for the sulfur atoms to sit results in a larger angle than that of the selenium atoms. No significant differences in the Pt-P bond lengths are observed between the complexes; however there are differences in the Pt-E bond lengths. The Pt-Se bond lengths of 2.432(2) $\AA$ and 2.4449(19) $\AA$ are longer than the Pt-S bond lengths of 2.326(2) $\AA$ and 2.3212(19) ̊.

As previously discussed for $\mathbf{1}$ and $\mathbf{3}$ the six-membered $\mathrm{PtE}_{2} \mathrm{C}_{3}$ chelate ring, that forms when the dichalcogenate ligand binds to the platinum centre, can be described as having a twisted envelope type conformation with the E $\cdots E$ vector as the hinge. In $1 \mathrm{C}(1), \mathrm{C}(10)$ and $\mathrm{C}(9)$ all lie in a plane with $\mathrm{S}(1)$ lying 0.525(1) $\AA$ below the plane and $\mathrm{S}(2)$ lying 0.449(1) $\AA$ above the plane. This results in a non-planar, twisted $\mathrm{PtS}_{2} \mathrm{C}_{3}$ ring. In 6 the $\mathrm{PtSe}_{2} \mathrm{C}_{3}$ ring is close to planar with the selenium atoms deviating from the plane by 0.012-0.019(1) $\AA$. The mean plane of $\mathrm{E}(1), \mathrm{E}(2), \mathrm{C}(1), \mathrm{C}(10)$ and $\mathrm{C}(9)$ and the displacement of $\operatorname{Pt}(1)$, which sits in the peri-gap above the plane, is measured. In 1 the $\operatorname{Pt}(1)$ sits $0.937(1)$ $\AA$ above the mean plane and the angle of the $\mathrm{S}(1) \cdots \mathrm{S}(2)$ hinge is $144.13(1)^{\circ}$. Whereas in 6 the $\operatorname{Pt}(1)$ sits $1.037(1) \AA$ above the mean plane and the $\mathrm{Se}(1) \cdots \operatorname{Se}(2)$ hinge angle is $142.98(1)^{\circ}$.

Unfortunately during our previous investigations the molecular structure of $\left[\mathrm{Pt}\left(\mathrm{NapS}_{2}\right)\left(\mathrm{PPh}_{3}\right)_{2}\right][10]$ could not be obtained and therefore a comparison of the different peri-dithiolate backbones and their effect on the platinum metal geometry cannot be discussed. However, molecular structures were obtained for the selenium complexes; $\left[\mathrm{Pt}\left(\mathrm{NapSe}_{2}\right)\left(\mathrm{PPh}_{3}\right)_{2}\right],[10]\left[\mathrm{Pt}\left(\mathrm{AcenapSe}_{2}\right)\left(\mathrm{PPh}_{3}\right)_{2}\right][11]$ and $\mathbf{6}$, allowing a direct comparison between backbones to me 
made. $\left[\mathrm{Pt}\left(\mathrm{NapSe}_{2}\right)\left(\mathrm{PPh}_{3}\right)_{2}\right][10]$ crystallises with two molecules in the asymmetric unit and one molecule of dichloromethane; $\left[\mathrm{Pt}\left(\mathrm{AcenapSe}_{2}\right)\left(\mathrm{PPh}_{3}\right)_{2}\right][11]$ and $\mathbf{6}$ crystallise as single molecules.

An increase in the non-bonded peri-distance is observed as the diselenolate ligand changes from naphthalene to acenaphthylene with values of 3.3721(9) $\AA$, 3.437(3) $\AA$ and 3.452(4) $\AA$ for $\left[\mathrm{Pt}\left(\mathrm{NapSe}_{2}\right)\left(\mathrm{PPh}_{3}\right)_{2}\right]$, $\left[\mathrm{Pt}\left(\mathrm{AcenapSe} \mathrm{S}_{2}\right)\left(\mathrm{PPh}_{3}\right)_{2}\right]$ and $\mathbf{6}$, respectively. This is accompanied by a steady increase in splay angle with values of $23.8^{\circ}, 25.7^{\circ}$ and $26.2^{\circ}$, respectively. This pattern is expected due to the addition of the ethane/ethene linker in acenaphthene/acenaphthylene causing the $\mathrm{C}(4)-\mathrm{C}(5)-\mathrm{C}(6)$ angle to decrease from $118.64(1)^{\circ}$ in $\left[\mathrm{Pt}\left(\mathrm{NapSe}_{2}\right)\left(\mathrm{PPh}_{3}\right)_{2}\right]$ to ca. $109^{\circ}$ in $\left[\mathrm{Pt}\left(\mathrm{AcenapSe}_{2}\right)\left(\mathrm{PPh}_{3}\right)_{2}\right]$ and $\mathbf{6}$. A decrease in this angle at the bottom of the ring causes an increase in the angles of the splay region which consequently leads to an increase in peri-distance. A decrease in out-of-plane distortion occurs with $\left[\mathrm{Pt}\left(\mathrm{NapSe}_{2}\right)\left(\mathrm{PPh}_{3}\right)_{2}\right]$ displaying the greatest out-of-plane displacement with one selenium atom lying 0.234(1) $\AA$ above the naphthyl plane and one 0.165(1) $\AA$ below. $\left[\operatorname{Pt}\left(\mathrm{NapSe}_{2}\right)\left(\mathrm{PPh}_{3}\right)_{2}\right]$ also has the largest deformation of the naphthalene scaffold with torsion angles varying from the 'ideal' $180^{\circ}$ by $1.1-2.4^{\circ}$. The naphthalene complex has the largest out-of-plane distortion and deformation of the backbone due to the absence of the ethane/ethene linker in the backbone which allows the system more flexibility.

The platinum metal adopts a distorted square planar geometry in all three complexes, with $\mathbf{6}$ displaying the most regular geometry. A steady increase in the $\mathrm{Se}(1)-\mathrm{Pt}(1)-\mathrm{Se}(2)$ angle is observed with values of $87.36(2)^{\circ}, 89.27(6)^{\circ}$ and $90.12(8)^{\circ}$ for $\left[\mathrm{Pt}\left(\mathrm{NapSe}_{2}\right)\left(\mathrm{PPh}_{3}\right)_{2}\right]$, $\left[\mathrm{Pt}(\mathrm{AcenapSe})_{2}\left(\mathrm{PPh}_{3}\right)_{2}\right]$ and $\mathbf{6}$, respectively. This increase is a direct consequence of the increasing splay angle which is caused by the compression of the $\mathrm{C}(4)-\mathrm{C}(5)-\mathrm{C}(6)$ angle. As the $\operatorname{Se}(1)-\mathrm{Pt}(1)-\operatorname{Se}(2)$ angle increases, and therefore becomes closer to the ideal ' $90^{\circ}$ ', the $\mathrm{P}(1)-\mathrm{Pt}(1)-\mathrm{P}(2)$ angle decreases with values of 98.40(6) ${ }^{\circ}, 97.68(13)^{\circ}$ and $96.98(11)^{\circ}$ for $\left[\mathrm{Pt}\left(\mathrm{NapSe}_{2}\right)\left(\mathrm{PPh}_{3}\right)_{2}\right]$, $\left[\mathrm{Pt}(\mathrm{AcenapSe})_{2}\left(\mathrm{PPh}_{3}\right)_{2}\right]$ and $\mathbf{6}$, respectively. No significant differences occur between the P-Pt-Se angles with values in the range of 86.5-88. $3^{\circ}$. There are no differences observed in the Pt bond lengths between complexes. However, within the complexes the $\mathrm{Pt}(1)$-Se bonds are longer ( $c a$. 2.43-2.45 ̊̊) than the Pt(1)-P bonds (ca. 2.28-2.30 ̊).

\section{Conclusions}

The work presented in this paper builds on our previous studies of platinum bisphosphine complexes bearing dichalcogenate based ligands.[11] Herein we present the synthesis of a related series of platinum complexes 1-4 and 6-8 prepared from acenaphtho[5,6-cd]-1,2-dichalcogenoles [AcenapylE 2$] \mathbf{L 1}(\mathrm{E}=\mathrm{S})$ and $\mathbf{L} 2(\mathrm{E}=\mathrm{Se})$ and cis-[ $\left.\mathrm{PtCl}_{2}\left(\mathrm{PR}_{3}\right)_{2}\right]$ $\left(\mathrm{R}_{3}=\mathrm{Ph}_{3}, \mathrm{Ph}_{2} \mathrm{Me}, \mathrm{PhMe}_{2}, \mathrm{Me}_{3}\right)$. For their synthesis, the appropriate disulfide or diselenide species was treated with lithium triethylborohydride resulting in in situ reduction of the AcenapylE $\mathrm{E}_{2} \mathrm{E}-\mathrm{E}$ bond to form the corresponding dilithio-species. Subsequent metathetical addition to a suspension of the cis- $\left[\mathrm{PtCl}_{2}\left(\mathrm{PR}_{3}\right)_{2}\right]$ in THF afforded the respective platinum(II) complexes $\left[\mathrm{Pt}\left(5,6-\mathrm{AcenapylE}_{2}\right)\left(\mathrm{PR}_{3}\right)_{2}\right]\left(\mathbf{1} \mathrm{E}=\mathrm{S}, \mathrm{R}_{3}=\mathrm{Ph}_{3} ; \mathbf{2} \mathrm{E}=\mathrm{S}, \mathrm{R}_{3}=\mathrm{Ph}_{2} \mathrm{Me} ; \mathbf{3} \mathrm{E}=\mathrm{S}, \mathrm{R}_{3}=\right.$ $\mathrm{PhMe}_{2} ; 4 \mathrm{E}=\mathrm{S}, \mathrm{R}_{3}=\mathrm{Me}_{3} ; 6 \mathrm{E}=\mathrm{Se}, \mathrm{R}_{3}=\mathrm{Ph}_{3} ; 7 \mathrm{E}=\mathrm{Se}, \mathrm{R}_{3}=\mathrm{Ph}_{2} \mathrm{Me} ; 8 \mathrm{E}=\mathrm{Se}, \mathrm{R}_{3}=\mathrm{PhMe}_{2}$ ). In a similar reaction, the dilithio-species of $\mathbf{L 1}$ and $\mathbf{L} 2$ were also reacted with (1,5-cyclooctadiene)platinum(II) dichloride; this led to only the formation of the $\mathbf{L} 1$ platinum complex [Pt(5,6-AcenapylS 2$)(\mathrm{COD})](\mathbf{5})$.

${ }^{31} \mathrm{P}\left\{{ }^{1} \mathrm{H}\right\}$ NMR spectra of the sulfur complexes, 1-4, display the expected single resonances with platinum satellites, moving to lower chemical shifts and with decreasing ${ }^{1} J\left({ }^{31} \mathrm{P}-{ }^{195} \mathrm{Pt}\right)$ coupling constants as the alkyl group on phosphorus 
is varied from $\mathrm{R}_{3}=\mathrm{Ph}_{3}$ to $\mathrm{R}_{3}=\mathrm{Me}_{3}$. In complexes 6-8, the addition of the low abundant ${ }^{77} \mathrm{Se} \mathrm{NMR}$ active isotope provides extra complexity to their respective ${ }^{31} \mathrm{P}\left\{{ }^{1} \mathrm{H}\right\}$ and ${ }^{77} \mathrm{Se}$ NMR spectra. Secondary isotopomer effects cause the two ${ }^{31} \mathrm{P}$ atoms to align with either a cis or trans configuration with respect to the ${ }^{77} \mathrm{Se}$ NMR active isotope, making them magnetically inequivalent and creating a complex satellite system.

The X-ray structure for the known compound $\mathbf{L 1}$ was investigated as no crystal data have been published.[3] It was found that $\mathbf{L 1}$ displays similar characteristics to naphtha[1,8-cd][1,2]dithiole $\left[\mathrm{NapS}_{2}\right][10]$ and 5,6dihydroacenaphtho[5,6-cd]-1,2-dithiole $\left[\mathrm{AcenapS}_{2}\right]$.[11] All three ligands were found to have statistically equivalent peri-distances and similar degrees of out-of-plane displacement and splay angle magnitude. L1 showed the largest, although still minor, deviation from the ideal $180^{\circ} \mathrm{C}-\mathrm{C}-\mathrm{C}-\mathrm{C}$ torsion angles by $1.88^{\circ}$ and $2.20^{\circ}$. X-ray structures determined for $\mathbf{1}, \mathbf{3}$ and $\mathbf{6}$ were analysed by platinum metal geometry, peri-atom displacement, splay angle magnitude, acenaphthylene ring torsion angles and $\mathrm{E} \cdots \mathrm{E}$ interactions. In each complex the acenaphtho[5,6-cd]-1,2-dichalcogenate ligand coordinates in a bidentate fashion to the platinum metal to form a six-membered $\mathrm{PtE}_{2} \mathrm{C}_{3}$ ring that can be described as having a twisted envelope type conformation. The platinum metal adopts a distorted square planar environment with angles deviating from the ideal $90^{\circ}$. Naturally, there is a significant increase in molecular distortion of the acenaphthylene ring system due to breaking of the chalcogen-chalcogen bond and insertion of the platinum. Complex 1 was found to have the greatest molecular distortion of all three complexes, showing that changing the phosphine group and also the chalcogen has a noticeable effect. Comparisons were made between $\mathbf{6}$ and our previously reported $\left[\mathrm{Pt}\left(\mathrm{NapSe}_{2}\right)\left(\mathrm{PPh}_{3}\right)_{2}\right]$ and $\left.\left[\mathrm{Pt}(\mathrm{AcenapSe})_{2}\right)\left(\mathrm{PPh}_{3}\right)_{2}\right]$ complexes; the level of distortion was found to decrease as the backbone is altered from naphthalene to acenaphthylene.

\section{Experimental Section}

All experiments were carried out under an oxygen- and moisture-free nitrogen atmosphere using standard Schlenk techniques and glassware. Reagents were obtained from commercial sources and used as received. Dry solvents were collected from a MBraun solvent system. Elemental analyses were performed by Stephen Boyer at the London Metropolitan University. Infra-red spectra were recorded for solids as $\mathrm{KBr}$ discs in the range $4000-350 \mathrm{~cm}^{-1}$ on a Perkin-Elmer System 2000 Fourier transform spectrometer. ${ }^{1} \mathrm{H},{ }^{13} \mathrm{C},{ }^{31} \mathrm{P}$ and ${ }^{77} \mathrm{Se}$ NMR were recorded on a Jeol GSX $270 \mathrm{MHz}$ spectrometer with $\delta(\mathrm{H})$ and $\delta(\mathrm{C})$ referenced to external tetramethylsilane, $\delta(\mathrm{P})$ referenced to external phosphoric acid and $\delta(\mathrm{Se})$ referenced to external dimethyl diselenide. Assignments of ${ }^{13} \mathrm{C}$ and ${ }^{1} \mathrm{H}$ NMR spectra were made with the help of H-H COSY and HSQC experiments. All measurements were performed at $25^{\circ} \mathrm{C}$. All values reported for NMR spectroscopy are in parts per million (ppm). Coupling constants $(J)$ are given in Hertz (Hz). Mass spectrometry was performed by the University of St. Andrews Mass Spectrometry Service. Electrospray Mass Spectrometry (ESMS) was carried out on a Micromass LCT orthogonal accelerator time of flight mass spectrometer. All cis-dichlorobis(phosphine)platinum reagents were prepared following standard literature procedures.[20,21,22] 5,6Dibromoacenaphthylene was also prepared following literature procedure.[13]

Acenaphtho[5,6-cd][1,2] dithiole [AcenapylS 2 ] (L1): TMEDA $(5.8 \mathrm{~mL}, 38.4 \mathrm{mmol})$ was added in one portion to a solution of 5,6-dibromoacenaphthylene $(5.95 \mathrm{~g}, 19.2 \mathrm{mmol})$ in diethyl ether $(250 \mathrm{~mL})$. The reaction was cooled to -78 ${ }^{\circ} \mathrm{C}$ and stirred for $15 \mathrm{~min}$. A $2.5 \mathrm{M}$ hexane solution of $n$-butyllithium $(7.7 \mathrm{~mL}, 19.2 \mathrm{mmol})$ was added dropwise and the mixture was stirred for $15 \mathrm{~min}$. Sulfur powder $(0.62 \mathrm{~g}, 19.3 \mathrm{mmol})$ was added and the mixture was stirred at $-40{ }^{\circ} \mathrm{C}$ for $2 \mathrm{~h}$. The mixture was cooled again to $-78{ }^{\circ} \mathrm{C}$ and a $2.5 \mathrm{M}$ hexane solution of $n$-butyllithium $(7.7 \mathrm{~mL}, 19.2 \mathrm{mmol})$ was 
added dropwise and the mixture was stirred for $15 \mathrm{~min}$. Sulfur powder $(0.62 \mathrm{~g}, 19.3 \mathrm{mmol})$ was added and the mixture was stirred at $-40{ }^{\circ} \mathrm{C}$ for a further $2 \mathrm{~h}$. The mixture was then warmed to room temperature, quenched with acetic acid $(2$ $\mathrm{mL}$ ) and exposed to an air stream overnight for mild oxidation. The resulting solution was evaporated under reduced pressure and then water $(200 \mathrm{~mL})$ was added and the mixture was extracted with dichloromethane $(4 \mathrm{x} 200 \mathrm{~mL})$. The extract was dried with anhydrous magnesium sulfate and concentrated under reduced pressure to give a deep red oil. The oil was dissolved in hexane $(100 \mathrm{~mL})$ and refluxed for an hour. The hot solution was placed in the freezer at - 30 ${ }^{\circ} \mathrm{C}$ overnight to yield an orange solid $(0.22 \mathrm{~g}, 5 \%)$; mp $166-168{ }^{\circ} \mathrm{C}$; elemental analysis(Found: $\mathrm{C}, 67.1$; H, 2.7. Calc. for $\mathrm{C}_{12} \mathrm{H}_{6} \mathrm{~S}_{2}: \mathrm{C}, 67.25 ; \mathrm{H}, 2.8 \%$ ); IR (KBr disc) $v_{\max } \mathrm{cm}^{-1} 3423 \mathrm{w}, 3035 \mathrm{w}, 2953 \mathrm{~s}, 2924 \mathrm{~s}, 2856 \mathrm{~s}, 1596 \mathrm{~s}, 1487 \mathrm{w}, 1462 \mathrm{~s}$, 1413vs, 1396vs, 1371vs, 1195w, 1108w, 1077s, 1025s, 823vs, 732w, 645w, 529w, 388w; ${ }^{1} \mathrm{H}$ NMR $\left(\mathrm{CDCl}_{3}, \mathrm{Me}_{4} \mathrm{Si}_{2} 270\right.$ $\mathrm{MHz}) \delta_{\mathrm{H}} 7.88\left(2 \mathrm{H}, \mathrm{d},{ }^{3} J_{\mathrm{HH}} 7.5 \mathrm{~Hz}\right.$, Acenapyl 4,7-H), $7.54\left(2 \mathrm{H}, \mathrm{d},{ }^{3} J_{\mathrm{HH}} 7.7 \mathrm{~Hz}\right.$, Acenapyl 3,8-H), 7.25 (2 H, s, Acenapyl

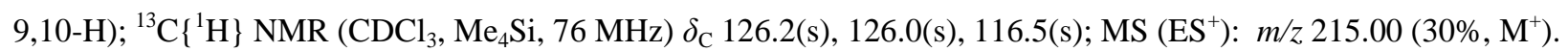

Acenaphtho[5,6-cd][1,2]diselenole [AcenapylSe $\mathbf{A}_{2}$ (L2): Ligand L2 was prepared following a similar procedure to that described for $\mathbf{L 1}$ using 5,6-dibromoacenaphthylene (2.27 g, $7.34 \mathrm{mmol}$ ), TMEDA (2.2 mL, $14.7 \mathrm{mmol}$ ), a $2.5 \mathrm{M}$ hexane solution of $n$-butyllithium $(5.9 \mathrm{~mL}, 14.7 \mathrm{mmol})$ and selenium powder $(1.16 \mathrm{~g}, 14.7 \mathrm{mmol})$ to yield a dark orange-brown

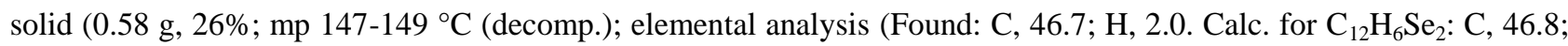
$\mathrm{H}, 2.0 \%$ ); IR (KBr disc) $v_{\max } \mathrm{cm}^{-1} 2921 \mathrm{w}, 2366 \mathrm{w}, 2344 \mathrm{w}, 1596 \mathrm{w}, 1463 \mathrm{w}, 1400 \mathrm{vs}, 1213 \mathrm{w}, 1079 \mathrm{~s}, 1020 \mathrm{~s}, 822 \mathrm{vs}, 793 \mathrm{~s}$, 726w, 639s, 496w; ${ }^{1} \mathrm{H}$ NMR $\left(\mathrm{CDCl}_{3}, \mathrm{Me}_{4} \mathrm{Si}, 270 \mathrm{MHz}\right) \delta_{\mathrm{H}} 7.76\left(2 \mathrm{H}, \mathrm{d},{ }^{3} \mathrm{~J}_{\mathrm{HH}} 7.5 \mathrm{~Hz}\right.$, Acenapyl 4,7-H), 7.66 (2 H, d, ${ }^{3} J_{\mathrm{HH}} 7.7 \mathrm{~Hz}$, Acenapyl 3,8-H), $7.17\left(2 \mathrm{H}, \mathrm{s}\right.$, Acenapyl 9,10-H); ${ }^{13} \mathrm{C}\left\{{ }^{1} \mathrm{H}\right\} \mathrm{NMR}\left(\mathrm{CDCl}_{3}, \mathrm{Me}_{4} \mathrm{Si}, 76 \mathrm{MHz}\right) \delta_{\mathrm{C}} 126.3(\mathrm{~s})$, 125.8(s), 121.4(s); $\delta_{\mathrm{Se}}\left(51.5 \mathrm{MHz} ; \mathrm{CDCl}_{3} ; 25^{\circ} \mathrm{C} ; \mathrm{MeSeSeMe}\right) 542.7(\mathrm{~s}) ; \mathrm{MS}\left(\mathrm{ES}^{+}\right): \mathrm{m} / z .310 .89\left(100 \%, \mathrm{M}^{+}\right)$.

$\left[\mathbf{P t}\left(\mathbf{P P h}_{\mathbf{3}}\right)_{\mathbf{2}} \mathbf{L 1}\right]$ (1): Lithium triethylborohydride $(0.95 \mathrm{~mL}$ of a $1.0 \mathrm{M}$ solution in $\mathrm{THF}, 0.95 \mathrm{mmol})$ was added to a solution of acenaphtho[5,6-cd][1,2]dithiole $(0.10 \mathrm{~g}, 0.47 \mathrm{mmol})$ in THF (20 mL). An immediate colour change occurred from orange to deep red, along with the evolution of gas. After stirring for $30 \mathrm{~min}$, the resulting solution was transferred via a stainless steel cannula to a suspension of $c i s$-dichlorobis(triphenylphosphine)platinum $(0.38 \mathrm{~g}, 0.47 \mathrm{mmol}) \mathrm{in} \mathrm{THF}$ $(10 \mathrm{~mL})$. The mixture was stirred for $24 \mathrm{~h}$ resulting in a red solution. The solution was poured through a shallow pad of silica and eluted with dichloromethane $(100 \mathrm{~mL})$. The filtrate was evaporated to dryness under reduced pressure and redissolved in dichloromethane $(10 \mathrm{~mL})$. Slow addition of a mixture of diethyl ether $(25 \mathrm{~mL})$ and hexane $(75 \mathrm{~mL})$ resulted in precipitation of a dark red solid, which was collected and dried in vacuo; $(0.10 \mathrm{~g}, 23 \%)$; mp $227-229{ }^{\circ} \mathrm{C}$ (decomp.); elemental analysis (Found: C, 57.9; H, 3.7. Calc. for $\mathrm{C}_{48} \mathrm{H}_{36} \mathrm{P}_{2} \mathrm{PtS}_{2} .1 .5 \times \mathrm{CH}_{2} \mathrm{Cl}_{2}$ : C, 57.8; $\mathrm{H}, 3.8 \%$ ); IR (KBr disc) $v_{\max } \mathrm{cm}^{-1} 3051 \mathrm{w}, 2361 \mathrm{w}, 1579 \mathrm{~s}, 1479 \mathrm{~s}, 1433 \mathrm{vs}, 1400 \mathrm{vs}, 1333 \mathrm{~s}, 1309 \mathrm{~s}, 1184 \mathrm{w}, 1115 \mathrm{~s}, 1097 \mathrm{vs}, 1073 \mathrm{vs}, 1032 \mathrm{vs}$, 998s, 828s, 737s, 691vs, 653s, 540vs, 521vs, 509vs, 495vs, 457w, 420w; ${ }^{1} \mathrm{H} \mathrm{NMR}\left(\mathrm{CDCl}_{3}, \mathrm{Me}_{4} \mathrm{Si}, 270 \mathrm{MHz}\right) \delta_{\mathrm{H}} 7.62-$ 7.44 (14 H, m, Acenapyl 4,7-H, P-Phenyl), 7.42-7.30 (6 H, m, P-Phenyl), 7.28 (2 H, d, ${ }^{3} J_{\mathrm{HH}} 5.3 \mathrm{~Hz}$, Acenapyl 3,8-H), 7.26-7.13 (12 H, m, P-Phenyl), 6.85 (2 H, s, Acenapyl 9,10-H); ${ }^{13} \mathrm{C}\left\{{ }^{1} \mathrm{H}\right\} \mathrm{NMR}\left(\mathrm{CDCl}_{3}, \mathrm{Me}_{4} \mathrm{Si}, 76 \mathrm{MHz}\right) \delta_{\mathrm{C}} 135.9-$ 135.2(m), 130.8(s), 128.5-127.9(m), 126.9-126.7(m), 125.3(s), 124.4(s); ${ }^{31} \mathrm{P}\left\{{ }^{1} \mathrm{H}\right\} \mathrm{NMR}\left(\mathrm{CDCl}_{3}, \mathrm{H}_{3} \mathrm{PO}_{4}, 203 \mathrm{MHz} \delta_{\mathrm{P}}\right.$ $23.9\left(\mathrm{~s},{ }^{1} J_{\mathrm{PPt}} 2953 \mathrm{~Hz}\right)$; MS $\left(\mathrm{ES}^{+}\right): \mathrm{m} / z 934.14\left(28 \%, \mathrm{M}^{+}\right)$.

[Pt(PPh $\left.\mathbf{P P e}_{2} \mathbf{L 1}\right]$ (2): Complex 2 was prepared following a similar procedure to that described for 1 using acenaphtho[5,6-cd][1,2]dithiole $(0.11 \mathrm{~g}, 0.49 \mathrm{mmol})$, lithium triethylborohydride $(0.95 \mathrm{~mL}$ of a $1.0 \mathrm{M}$ solution in THF, $0.95 \mathrm{mmol})$, and cis- dichlorobis(diphenylmethylphosphine)platinum (0.32 g, $0.49 \mathrm{mmol})$ to yield an orange solid (0.17 g, 42\%); mp $117-119{ }^{\circ} \mathrm{C}$ (decomp.); elemental analysis (Found: C, 54.4; H, 3.8. Calc. for $\mathrm{C}_{38} \mathrm{H}_{32} \mathrm{PtP}_{2} \mathrm{~S}_{2} .1 / 2 \mathrm{CH}_{2} \mathrm{Cl}_{2}: \mathrm{C}_{\text {, }}$ 
54.3; H, 3.9\%); IR (KBr disc) $v_{\max } \mathrm{cm}^{-1} 3424 \mathrm{w}, 3053 \mathrm{w}, 2922 \mathrm{w}, 2363 \mathrm{~s}, 2342 \mathrm{w}, 1576 \mathrm{w}, 1463 \mathrm{w}, 1436 \mathrm{~s}, 1402 \mathrm{vs}, 1332 \mathrm{~s}$, 1310w, 1180w, 1102s, 1072s, 1035s, 890vs, 830w, 736s, 693s, 510s, 452w; ${ }^{1} \mathrm{H}$ NMR $\left(\mathrm{CDCl}_{3}, \mathrm{Me}_{4} \mathrm{Si}, 270 \mathrm{MHz}\right) \delta_{\mathrm{H}}$ $7.52\left(2 \mathrm{H}, \mathrm{d},{ }^{3} \mathrm{~J}_{\mathrm{HH}} 7.4 \mathrm{~Hz}\right.$, Acenapyl 4,7-H), 7.49-7.42 (8 H, m, P-Phenyl), 7.38-7.28 (4 H, m, P-Phenyl), 7.28-7.18 (8 H, m, P-Phenyl), 7.11-7.04 (2 H, m, Acenapyl 3,8-H), 6.80 (2 H, s, Acenapyl 9,10-H), $1.83\left(6 \mathrm{H}, \mathrm{d},{ }^{1} J_{P H} 9.4 \mathrm{~Hz}\right) ;{ }^{13} \mathrm{C}\left\{{ }^{1} \mathrm{H}\right\}$ $\mathrm{NMR}\left(\mathrm{CDCl}_{3}, \mathrm{Me}_{4} \mathrm{Si}, 76 \mathrm{MHz}\right) \delta_{\mathrm{C}} 133.6-133.5(\mathrm{~m}), 131.1(\mathrm{~s}), 128.8-128.6(\mathrm{~m}), 126.7(\mathrm{~s}), 125.0(\mathrm{~s}), 124.4(\mathrm{~s}), 14.6\left(\mathrm{~d},{ }^{1} J_{C P}\right.$ $41 \mathrm{~Hz}) ;{ }^{31} \mathrm{P}\left\{{ }^{1} \mathrm{H}\right\} \mathrm{NMR}\left(\mathrm{CDCl}_{3}, \mathrm{H}_{3} \mathrm{PO}_{4}, 203 \mathrm{MHz}\right) \delta_{\mathrm{P}} 3.5\left(\mathrm{~s},{ }^{1} J_{\mathrm{PPt}} 2880 \mathrm{~Hz}\right) ; \mathrm{MS}\left(\mathrm{ES}^{+}\right): m / z 796.20\left(100 \%, \mathrm{M}^{+}-\mathrm{Me}\right)$.

[Pt(PPhMe $\left.)_{2}\right)_{2} \mathbf{L 1}$ (3): Complex 3 was prepared following a similar procedure to that described for 1 using acenaphtho[5,6-cd][1,2]dithiole $(0.11 \mathrm{~g}, 0.51 \mathrm{mmol})$, lithium triethylborohydride $(0.95 \mathrm{~mL}$ of a $1.0 \mathrm{M}$ solution in THF, $0.95 \mathrm{mmol})$, and cis- dichlorobis(dimethylphenylphosphine)platinum (0.26 g, $0.48 \mathrm{mmol})$ to yield an orange solid (0.09 g, 27\%); mp 68-70 ${ }^{\circ} \mathrm{C}$ (decomp.); elemental analysis (Found: C, 48.95; H, 4.0. Calc. for $\mathrm{C}_{28} \mathrm{H}_{28} \mathrm{PtP}_{2} \mathrm{~S}_{2}$ : C, 49.05; H, $4.1 \%$ ); IR (KBr disc) $v_{\max } \mathrm{cm}^{-1} 3425 \mathrm{w}, 2913 \mathrm{w}, 1577 \mathrm{~s}, 1462 \mathrm{w}, 1435 \mathrm{~s}, 1402 \mathrm{vs}, 1332 \mathrm{w}, 1308 \mathrm{w}, 1176 \mathrm{w}, 1107 \mathrm{~s}, 1072 \mathrm{~s}$, 948s, 911vs, 836vs, 744s, 716w, 694s, 654w, 533w, 488w, 444w; ${ }^{1} \mathrm{H}$ NMR $\left(\mathrm{CDCl}_{3}, \mathrm{Me}_{4} \mathrm{Si}, 270 \mathrm{MHz}\right) \delta_{\mathrm{H}} 7.82(2 \mathrm{H}, \mathrm{d}$, ${ }^{3} J_{\mathrm{HH}} 7.5 \mathrm{~Hz}$, Acenapyl 4,7-H), 7.45-7.36 (4 H, m, P-Phenyl), 7.39 (2 H, d, ${ }^{3} J_{\mathrm{HH}} 7.5 \mathrm{~Hz}$, Acenapyl 3,8-H), 7.35-7.27 (2 H, m, P-Phenyl), 7.26-7.17 (4 H, m, P-Phenyl), $6.87\left(2 \mathrm{H}, \mathrm{s}\right.$, Acenapyl 9,10-H), $1.62\left(12 \mathrm{H}, \mathrm{d},{ }^{1} J_{P H} 10.0 \mathrm{~Hz}\right) ;{ }^{13} \mathrm{C}\left\{{ }^{1} \mathrm{H}\right\}$ NMR $\left(\mathrm{CDCl}_{3}, \mathrm{Me}_{4} \mathrm{Si}, 76 \mathrm{MHz}\right) \delta_{\mathrm{C}}$ 131.8-131.4(m), 129.4(br s), 129.1-129.0(m), 126.7(s), 124.8(s), 124.4(s), 13.7 (d, $\left.{ }^{1} J_{C P} 40 \mathrm{~Hz}\right) ;{ }^{31} \mathrm{P}\left\{{ }^{1} \mathrm{H}\right\} \mathrm{NMR}\left(\mathrm{CDCl}_{3}, \mathrm{H}_{3} \mathrm{PO}_{4}, 203 \mathrm{MHz}\right) \delta_{\mathrm{P}}-14.5\left(\mathrm{~s},{ }^{1} J_{P P t} 2819 \mathrm{~Hz}\right)$; MS $\left(\mathrm{ES}^{+}\right): \mathrm{m} / z .578 .08\left(100 \%, \mathrm{M}^{+}-\right.$ $\mathrm{PhMe}_{2}$ ).

[Pt(PMe $\left.)_{2}\right)_{2} \mathbf{L 1}$ (4): Complex 4 was prepared following a similar procedure to that described for $\mathbf{1}$ using acenaphtho[5,6- $c d][1,2]$ dithiole $(0.10 \mathrm{~g}, 0.48 \mathrm{mmol})$, lithium triethylborohydride $(0.95 \mathrm{~mL}$ of a $1.0 \mathrm{M}$ solution in THF, $0.95 \mathrm{mmol})$, and cis-dichlorobis(trimethylphosphine)platinum $(0.20 \mathrm{~g}, 0.48 \mathrm{mmol})$ to yield an impure brown solid; ${ }^{31} \mathrm{P}\left\{{ }^{1} \mathrm{H}\right\} \mathrm{NMR}\left(\mathrm{CDCl}_{3}, \mathrm{H}_{3} \mathrm{PO}_{4}, 203 \mathrm{MHz}\right) \delta_{\mathrm{P}}-24.7\left(\mathrm{~s},{ }^{1} J_{P P t} 2768 \mathrm{~Hz}\right)$.

[Pt(COD)L1] (5): Complex 5 was prepared following a similar procedure to that described for $\mathbf{1}$ using acenaphtho[5,6$c d][1,2]$ dithiole $(0.10 \mathrm{~g}, 0.47 \mathrm{mmol})$, lithium triethylborohydride $(0.95 \mathrm{~mL}$ of a $1.0 \mathrm{M}$ solution in THF, $0.95 \mathrm{mmol})$, and (1,5-cyclooctadiene)platinum(II) dichloride $(0.18 \mathrm{~g}, 0.47 \mathrm{mmol})$ to yield an orange solid $(0.04 \mathrm{~g}, 14 \%)$; $\mathrm{mp}>300{ }^{\circ} \mathrm{C}$; elemental analysis (Found: C, 46.3; H, 3.6. Calc. for $\mathrm{C}_{20} \mathrm{H}_{18} \mathrm{PtS}_{2}$ : C, 46.4; H, 3.5\%); IR (KBr disc) $v_{\max } \mathrm{cm}^{-1} 2923 \mathrm{~s}$, 2872s, 2363s, 2343w, 1580w, 1462w, 1408vs, 1335w, 1261s, 1179w, 1073vs, 1034vs, 831s, 800s, 729w, 651w, 535w; ${ }^{1} \mathrm{H} \mathrm{NMR}\left(\mathrm{CDCl}_{3}, \mathrm{Me}_{4} \mathrm{Si}, 270 \mathrm{MHz}\right) \delta_{\mathrm{H}} 7.73\left(2 \mathrm{H}, \mathrm{d},{ }^{3} J_{\mathrm{HH}} 7.5 \mathrm{~Hz}\right.$, Acenapyl 4,7-H), $7.48\left(2 \mathrm{H}, \mathrm{d},{ }^{3} J_{\mathrm{HH}} 7.5 \mathrm{~Hz}\right.$, Acenapyl 3,8-H), 6.97 (2 H, s, Acenapyl 9,10-H), 5.18 (4 H, s, COD-CH $)_{2}, 2.71-2.59$ (4 H, m, COD-CH $)_{2}, 2.55-2.34$ (4 H, m, $\left.\mathrm{COD}-\mathrm{CH}_{2}\right) ;{ }^{13} \mathrm{C}\left\{{ }^{1} \mathrm{H}\right\}$ NMR $\left(\mathrm{CDCl}_{3}, \mathrm{Me}_{4} \mathrm{Si}, 76 \mathrm{MHz}\right) \delta_{\mathrm{C}} 125.6(\mathrm{~s}), 125.3(\mathrm{~s}), 124.6(\mathrm{~s}), 100.6(\mathrm{~s}), 30.7(\mathrm{~s}) ; \mathrm{MS}\left(\mathrm{ES}^{+}\right): \mathrm{m} / z$ $518.06\left(100 \%, \mathrm{M}^{+}+\mathrm{H}\right)$.

[Pt $\left.\left(\mathbf{P P h}_{3}\right)_{2} \mathbf{L 2}\right]$ (6): Complex $\mathbf{6}$ was prepared following a similar procedure to that described for $\mathbf{1}$ using acenaphtho[5,6$c d][1,2]$ diselenole $(0.10 \mathrm{~g}, 0.34 \mathrm{mmol})$, lithium triethylborohydride $(0.65 \mathrm{~mL}$ of a $1.0 \mathrm{M}$ solution in THF, $0.65 \mathrm{mmol})$, and cis- dichlorobis(triphenylphosphine)platinum $(0.26 \mathrm{~g}, 0.33 \mathrm{mmol})$ to yield a red solid $(0.16 \mathrm{~g}, 48 \%)$; mp 159-161 ${ }^{\circ} \mathrm{C}$; elemental analysis (Found: C, 55.9; H, 3.6. Calc. for $\mathrm{C}_{48} \mathrm{H}_{36} \mathrm{PtP}_{2} \mathrm{Se}_{2}$ : C, 56.1; H, 3.5\%); IR (KBr disc) $v_{\max } \mathrm{cm}^{-1}$ 3408w, 3052w, 2925w, 1581w, 1479s, 1435vs, 1400vs, 1331s, 1185w, 1159w, 1094vs, 1073s, 1026s, 1000w, 831w, 743s, 693vs, 646w, 539vs, 522vs, 496s, 459w, 422w; ${ }^{1} \mathrm{H}$ NMR $\left(\mathrm{CDCl}_{3}, \mathrm{Me}_{4} \mathrm{Si}, 270 \mathrm{MHz}\right) \delta_{\mathrm{H}} 7.70\left(2 \mathrm{H}, \mathrm{d},{ }^{3} J_{\mathrm{HH}} 7.3 \mathrm{~Hz}\right.$, Acenapyl 4,7-H), 7.60-7.48 (12 H, m, P-Phenyl), 7.39-7.27 (8 H, m, Acenapyl 3, 8-H, P-Phenyl), 7.25-7.12 (12 H, m, 
P-Phenyl), 6.85 (2 H, s, Acenapyl 9,10-H); ${ }^{13} \mathrm{C}\left\{{ }^{1} \mathrm{H}\right\} \mathrm{NMR}\left(\mathrm{CDCl}_{3}, \mathrm{Me}_{4} \mathrm{Si}, 76 \mathrm{MHz}\right) \delta_{\mathrm{C}}$ 135.8-135.0(m), 130.8(s), 129.7(br s), 128.3-127.8(m), 125.9(s), 124.2(s); ${ }^{31} \mathrm{P}\left\{{ }^{1} \mathrm{H}\right\} \mathrm{NMR}\left(\mathrm{CDCl}_{3}, \mathrm{H}_{3} \mathrm{PO}_{4}, 203 \mathrm{MHz}\right) \delta_{\mathrm{P}} 20.2\left(\mathrm{~s},{ }^{1} J_{P P t} 3014 \mathrm{~Hz}\right)$;

${ }^{77} \mathrm{Se}\left\{{ }^{1} \mathrm{H}\right\} \mathrm{NMR}\left(\mathrm{CDCl}_{3}, \mathrm{Me}_{2} \mathrm{Se}_{2}, 51.5 \mathrm{MHz}\right) \delta_{\mathrm{Se}} 227.6$ (pseudo-triplet, $\left.{ }^{1}{ }^{2} J_{\mathrm{SeP}} 55 \mathrm{~Hz},{ }^{1} J_{\mathrm{SePt}} 178 \mathrm{~Hz}\right) ; \mathrm{MS}\left(\mathrm{ES}^{+}\right): \mathrm{m} / z$ $1028.03\left(100 \%, \mathrm{M}^{+}+\mathrm{H}\right)$.

[Pt $\left.\left(\mathbf{P P h}_{2} \mathbf{M e}\right)_{2} \mathbf{L 2}\right]$ (7): Complex 7 was prepared following a similar procedure to that described for $\mathbf{1}$ using acenaphtho[5,6-cd][1,2]diselenole $(0.10 \mathrm{~g}, 0.33 \mathrm{mmol})$, lithium triethylborohydride $(0.66 \mathrm{~mL}$ of a $1.0 \mathrm{M}$ solution in THF, $0.66 \mathrm{mmol}$ ), and cis- dichlorobis(diphenylmethylphosphine)platinum $(0.21 \mathrm{~g}, 0.32 \mathrm{mmol})$ to yield a red solid (0.07 g, 25\%); mp 116-118 ${ }^{\circ} \mathrm{C}$; elemental analysis (Found: C, 50.4; H, 3.7. Calc. for $\mathrm{C}_{38} \mathrm{H}_{32} \mathrm{PtP}_{2} \mathrm{Se}_{2}$ : C, 50.5; H, 3.6\%); IR (KBr disc) $v_{\max } \mathrm{cm}^{-1} 3422 \mathrm{w}, 3051 \mathrm{w}, 2922 \mathrm{w}, 2361 \mathrm{~s}, 2343 \mathrm{w}, 1579 \mathrm{~s}, 1561 \mathrm{w}, 1475 \mathrm{~s}, 1435 \mathrm{vs}, 1399 \mathrm{vs}, 1330 \mathrm{~s}, 1182 \mathrm{w}$, 1101s, 1072s, 1026s, 999w, 889vs, 831s, 734s, 693vs, 647w, 509s, 490s, 451s; ${ }^{1} \mathrm{H}$ NMR $\left(\mathrm{CDCl}_{3}, \mathrm{Me}_{4} \mathrm{Si}, 270 \mathrm{MHz}\right) \delta_{\mathrm{H}}$ $7.87\left(2 \mathrm{H}, \mathrm{d},{ }^{3} \mathrm{~J}_{\mathrm{HH}} 7.3 \mathrm{~Hz}\right.$, Acenapyl 4,7-H), 7.49-7.38 (8 H, m, P-Phenyl), 7.49-7.38 (4 H, m, P-Phenyl), 7.38-7.29 (8 H, m, P-Phenyl), $7.25\left(2 \mathrm{H}, \mathrm{d},{ }^{3} J_{\mathrm{HH}} 7.4 \mathrm{~Hz}\right.$, Acenapyl 3,8-H), $6.85\left(2 \mathrm{H}, \mathrm{s}\right.$, Acenapyl 9,10-H), $1.91\left(6 \mathrm{H}, \mathrm{d},{ }^{1} J_{P H} 8.9 \mathrm{~Hz}\right)$; ${ }^{13} \mathrm{C}\left\{{ }^{1} \mathrm{H}\right\} \mathrm{NMR}\left(\mathrm{CDCl}_{3}, \mathrm{Me}_{4} \mathrm{Si}, 76 \mathrm{MHz}\right) \delta_{\mathrm{C}} 133.5\left(\mathrm{~d},{ }^{2} J_{C P} 6.8 \mathrm{~Hz}\right), 131.8(\mathrm{~s}), 129.7\left(\mathrm{~d},{ }^{4} J_{C P} 4.3 \mathrm{~Hz}\right), 128.7\left(\mathrm{~d},{ }^{3} J_{C P} 4.9\right.$ $\mathrm{Hz}), 125.9(\mathrm{~s}), 124.2(\mathrm{~s}), 15.5$ (br s); ${ }^{31} \mathrm{P}\left\{{ }^{1} \mathrm{H}\right\} \mathrm{NMR}\left(\mathrm{CDCl}_{3}, \mathrm{H}_{3} \mathrm{PO}_{4}, 203 \mathrm{MHz}\right) \delta_{\mathrm{P}} 0.6\left(\mathrm{~s},{ }^{1} \mathrm{JPP}_{\mathrm{Pt}} 2932 \mathrm{~Hz}\right) ;{ }^{77} \mathrm{Se}\left\{{ }^{1} \mathrm{H}\right\} \mathrm{NMR}$ $\left(\mathrm{CDCl}_{3}, \mathrm{Me}_{2} \mathrm{Se}_{2}, 51.5 \mathrm{MHz}\right) \delta_{\mathrm{Se}} 204.5$ (pseudo-triplet, $\left.{ }^{12} J_{\text {SeP }} 55 \mathrm{~Hz},{ }^{1} J_{S e P t} 210 \mathrm{~Hz}\right) ; \mathrm{MS}\left(\mathrm{ES}^{+}\right): \mathrm{m} / z 750.06\left(45 \%, \mathrm{M}^{+}-\right.$ $\left.\mathrm{Ph}_{2}\right)$.

$\left[\operatorname{Pt}(\mathbf{P P h M e})_{2} \mathbf{L 2}\right](\mathbf{8})$ : Complex 8 was prepared following a similar procedure to that described for $\mathbf{1}$ using acenaphtho[5,6-cd][1,2]diselenole $(0.10 \mathrm{~g}, 0.34 \mathrm{mmol})$, lithium triethylborohydride $(0.65 \mathrm{~mL}$ of a $1.0 \mathrm{M}$ solution in THF, $0.65 \mathrm{mmol})$, and cis- dichlorobis(dimethylphenylphosphine)platinum $(0.18 \mathrm{~g}, 0.33 \mathrm{mmol})$ to yield a red solid (0.06 g, 22\%); mp 66-68 ${ }^{\circ} \mathrm{C}$ (decomp.); IR (KBr disc) $v_{\max } \mathrm{cm}^{-1} 3423 \mathrm{vs}, 3050 \mathrm{w}, 2908 \mathrm{w}, 2361 \mathrm{w}, 2344 \mathrm{w}, 1638 \mathrm{w}, 1579 \mathrm{~s}$, $1561 \mathrm{w}, 1467 \mathrm{w}, 1435 \mathrm{~s}, 1398 \mathrm{vs}, 1329 \mathrm{~s}, 1312 \mathrm{w}, 1283 \mathrm{w}, 1181 \mathrm{w}, 1105 \mathrm{~s}, 1072 \mathrm{~s}, 1027 \mathrm{~s}, 1000 \mathrm{w}, 1105 \mathrm{~s}, 1072 \mathrm{~s}, 1027 \mathrm{~s}$, 946vs, 908vs, 834s, 743s, 714s, 694s, 647s, 489s, 443s, 371w; ${ }^{1} \mathrm{H}$ NMR $\left(\mathrm{CDCl}_{3}, \mathrm{Me}_{4} \mathrm{Si}, 270 \mathrm{MHz}\right) \delta_{\mathrm{H}} 8.14\left(2 \mathrm{H}, \mathrm{d},{ }^{3} J_{\mathrm{HH}}\right.$ 7.2 Hz, Acenapyl 4,7-H), 7.62-7.49 (4 H, m, P-Phenyl), 7.50-7.30 (8 H, m, P-Phenyl, Acenapyl 3,8-H), 6.92 (2 H, s, Acenapyl 9,10-H), $1.72\left(12 \mathrm{H}, \mathrm{d},{ }^{1} J_{P H} 9.7 \mathrm{~Hz}\right) ;{ }^{13} \mathrm{C}\left\{{ }^{1} \mathrm{H}\right\} \mathrm{NMR}\left(\mathrm{CDCl}_{3}, \mathrm{Me}_{4} \mathrm{Si}, 76 \mathrm{MHz}\right) \delta_{\mathrm{C}} 131.5-131.1(\mathrm{~m}), 129.8(\mathrm{~s})$, 129.5(br s), 129.1-128.9(m), 125.8(s), 124.3(s), $14.5\left(\mathrm{~d},{ }^{1} J_{\mathrm{CP}} 40 \mathrm{~Hz}\right) ;{ }^{31} \mathrm{P}\left\{{ }^{1} \mathrm{H}\right\} \mathrm{NMR}\left(\mathrm{CDCl}_{3}, \mathrm{H}_{3} \mathrm{PO}_{4}, 203 \mathrm{MHz}\right) \delta_{\mathrm{P}}-17.6$ (s, $\left.{ }^{1} J_{\mathrm{PPt}} 2873 \mathrm{~Hz},{ }^{2} J_{\mathrm{PSe}} 52 \mathrm{~Hz}\right) ;{ }^{77} \mathrm{Se}\left\{{ }^{1} \mathrm{H}\right\} \mathrm{NMR}\left(\mathrm{CDCl}_{3}, \mathrm{Me}_{2} \mathrm{Se}_{2}, 51.5 \mathrm{MHz}\right) \delta_{\mathrm{Se}} 174.6$ (pseudo triplet, ${ }^{1} J_{\mathrm{SeP}} 53 \mathrm{~Hz},{ }^{1} J_{\mathrm{SePt}}$ $251 \mathrm{~Hz}) ; \mathrm{MS}\left(\mathrm{ES}^{+}\right): \mathrm{m} / z .786 .04\left(60 \%, \mathrm{M}^{+}+\mathrm{Li}\right)$.

\section{Crystal Structure Analyses}

X-ray crystal structures for $\mathbf{L 1}$ and 3 were determined at $-100(1){ }^{\circ} \mathrm{C}$ and $-180(1){ }^{\circ} \mathrm{C}$, respectively, using a Rigaku XtaLAB P200 diffractometer (Mo Ka radiation, confocal optic). Intensities were corrected for Lorentz, polarisation and absorption. Data for compound 1 were collected at $-180(1){ }^{\circ} \mathrm{C}$ by using a Rigaku MM007 High brilliance RA generator (Mo $\mathrm{K} \alpha$ radiation, confocal optic) and Saturn CCD system. At least a full hemisphere of data was collected using $\omega$ scans. Intensities were corrected for Lorentz, polarisation and absorption. Data for compound $\mathbf{6}$ were collected at $100(1){ }^{\circ} \mathrm{C}$ on a Rigaku SCXmini CCD area detector with graphite-monochromated Mo-K $\alpha$ radiation $(\lambda=0.71073 \AA$ ). The data were corrected for Lorentz, polarisation and absorption. Data for all compounds analyzed were collected and processed using CrystalClear (Rigaku).[23] Structures were solved by direct methods[24] and expanded using Fourier techniques.[25] Non-hydrogen atoms were refined anisotropically. Hydrogen atoms were refined using the riding model. All calculations were performed using the CrystalStructure[26] crystallographic software package except for 
refinement, which was performed using SHELXL2013.[27] All images of molecular structures were generated using OLEX2.[28]

Table 4. Crystallographic data for compounds $\mathbf{L 1}, \mathbf{1}, \mathbf{3}$, and 6.

\begin{tabular}{|c|c|c|c|c|}
\hline Compound & L1 & 1 & 3 & 6 \\
\hline Empirical Formula & $\mathrm{C}_{12} \mathrm{H}_{6} \mathrm{~S}_{2}$ & $\mathrm{C}_{49.5} \mathrm{H}_{39} \mathrm{Cl}_{3} \mathrm{P}_{2} \mathrm{PtS}_{2}$ & $\mathrm{C}_{28} \mathrm{H}_{28} \mathrm{P}_{2} \mathrm{PtS}_{2}$ & $\mathrm{C}_{48} \mathrm{H}_{36} \mathrm{P}_{2} \mathrm{PtSe}_{2}$ \\
\hline Formula Weight & 214.30 & 1061.37 & 685.69 & 1027.77 \\
\hline Temperature $\left({ }^{\circ} \mathrm{C}\right)$ & -100.0 & -180.0 & -180.0 & -100.0 \\
\hline Crystal Colour, Habit & orange, chip & red, prism & orange, prism & red, prism \\
\hline Crystal Dimensions $\left(\mathrm{mm}^{3}\right)$ & $0.090 \times 0.050 \times 0.020$ & $0.100 \times 0.100 \times 0.100$ & $0.100 \times 0.100 \times 0.020$ & $0.129 \times 0.122 \times 0.079$ \\
\hline Crystal System & monoclinic & orthorhombic & monoclinic & monoclinic \\
\hline \multirow[t]{6}{*}{ Lattice Parameters } & $\mathrm{a}=7.4390(19) \AA$ & $\mathrm{a}=21.978(4) \AA$ & $a=15.708(4) \AA$ & $\mathrm{a}=9.943(11) \AA$ \\
\hline & $\mathrm{b}=11.323(3) \AA$ & $\mathrm{b}=58.311(10) \AA$ & $\mathrm{b}=9.991(2) \AA$ & $\mathrm{b}=17.589(18) \AA$ \\
\hline & $\mathrm{c}=11.165(3) \AA$ & $\mathrm{c}=13.808(3) \AA$ & $\mathrm{c}=16.400(4) \AA$ & $\mathrm{c}=22.95(2) \AA$ \\
\hline & - & - & - & - \\
\hline & $\beta=105.277(5)^{\circ}$ & - & $\beta=93.805(5)^{\circ}$ & $\beta=101.467(10)^{\circ}$ \\
\hline & - & - & - & - \\
\hline Volume $\left(\AA^{3}\right)$ & $907.2(4)$ & $17696(6)$ & $2567.9(11)$ & $3933(7)$ \\
\hline Space Group & $\mathrm{P} 2{ }_{1} / \mathrm{c}$ & Fdd 2 & $\mathrm{P} 2{ }_{1} / \mathrm{c}$ & $\mathrm{P} 2{ }_{1} / \mathrm{n}$ \\
\hline Z Value & 4 & 16 & 4 & 4 \\
\hline Dcalc $\left(\mathrm{g} / \mathrm{cm}^{3}\right)$ & 1.608 & 1.593 & 1.773 & 1.735 \\
\hline F000 & 440 & 8432 & 1344 & 2000 \\
\hline$\mu(\operatorname{MoK} \alpha)\left(\mathrm{cm}^{-1}\right)$ & 5.314 & 33.414 & 57.453 & 55.198 \\
\hline No. of Reflections Measured & 10802 & 43690 & 33538 & 18295 \\
\hline Rint & 0.0599 & 0.0549 & 0.1227 & 0.0902 \\
\hline Min and Max Transmissions & $0.823-0.989$ & $0.541-0.702$ & $0.422-0.891$ & $0.451-0.647$ \\
\hline Independ. Reflection (No. Variables) & 1663(154) & $8004(532)$ & $4739(302)$ & 7187(478) \\
\hline Reflection/Parameter Ratio & 10.80 & 15.05 & 15.69 & 15.04 \\
\hline Residuals: R1 (I>2.00б(I)) & 0.0362 & 0.0407 & 0.1344 & 0.0536 \\
\hline Residuals: R (All Reflections) & 0.0516 & 0.0415 & 0.1484 & 0.1124 \\
\hline Residuals: wR 2 (All Reflections) & 0.0975 & 0.0979 & 0.3760 & 0.0836 \\
\hline Goodness of Fit Indicator & 1.000 & 1.056 & 1.156 & 1.051 \\
\hline Maximum peak in Final Diff. Map & $0.34 \mathrm{e}-/ \AA^{3}$ & $2.81 \mathrm{e}-/ \AA^{3}$ & $11.74 \mathrm{e}-/ \AA^{3}$ & $1.15 \mathrm{e}-/ \AA^{3}$ \\
\hline Minimum peak in Final Diff. Map & $-0.24 \mathrm{e}-/ \AA^{3}$ & $-1.24 \mathrm{e}^{-} / \AA^{3}$ & $-5.77 \mathrm{e}^{-} / \AA^{3}$ & $-1.53 \mathrm{e}^{-} / \AA^{3}$ \\
\hline
\end{tabular}

CCDC <1005370-1005373 contains the supplementary crystallographic data for $\mathbf{L 1}, \mathbf{1}, \mathbf{3} \& \mathbf{6}$. These X-ray data can be obtained free of charge via www.ccdc.cam.ac.uk/conts/retrieving.html or from the Cambridge Crystallographic Data centre, 12 Union Road, Cambridge CB2 1EZ, UK; fax (+44) 1223-336-033; e-mail: deposit@ccdc.cam.ac.uk CCDC Nos:

\section{Acknowledgments}

Mass Spectrometry was performed at the University of St. Andrews Mass Spectrometry Service by Caroline Horsburgh. The work in this project was supported by the Engineering and Physical Sciences Research Council (EPSRC). 


\section{References}

[1] a) C. A. Coulson, R. Daudel, J. M. Robertson, Proc. R. Soc. London, Ser. A 1951, 207, 306; b) D. W. Cruickshank, Acta Crystallogr. 1957, 10, 504; c) C. P. Brock, J. D. Dunitz, Acta Crystallogr., Sect. B: Struct. Crystallogr. Cryst. Chem. 1982, 38, 2218; d) J. Oddershede, S. Larsen, J. Phys. Chem. A 2004, 108, 1057.

[2] A. C. Hazell, R. G. Hazell, L. Norskov-Lauritsen, C. E. Briant, D. W. Jones, Acta Crystallogr., Sect. C: Cryst. Struct. Commun. 1986, 42, 690.

[3] A. D. Rae, R. A. Wood, T. R. Welberry, J. Chem. Soc., Perkin Trans. 2 1985, 3, 451.

[4] A. Bondi, J. Phys. Chem. 1964, 68, 441.

[5] V. Balasubramaniyan, Chem. Rev. 1966, 66, 567.

[6] R. W. Alder, P. S. Bowman, W. R. S. Steele, D. R. Winterman, Chem. Commun. 1968, 723; b) R. W. Alder, M. R. Bryce, N. C. Goode, N. Miller, J. Owen, J. Chem. Soc., Perkin Trans. 1 1981, 2840; c) J. D. Hoefelmeyer, M. Schulte, M. Tschinkl, F. P. Gabbai, Coord. Chem. Rev. 2002, 235, 93; d) P. Kilian, F. R. Knight, J. D. Woollins, Chem. Eur. J. 2011, 17, 2302; e) P. Kilian, F. R. Knight, J. D. Woollins, Coord. Chem. Rev. 2011, 255, 1387.

[7] a) P. Wawrzyniak, A. M. Z. Slawin, A. L. Fuller, J. D. Woollins, P. Kilian, Dalton Trans. 2009, 38, 7883; b) V. V. Mezheritskii, A. N. Antonov, A. A. Milov, K. A. Lysenko, Russ. J. Org. Chem. 2010, 46(6), 844; c) F. R. Knight, K. S. Athukorala Arachchige, R. A. M. Randall, M. Bühl, A. M. Z. Slawin, J. D. Woollins, Dalton Trans. 2012, 41(11), 3154; d) M-L. Lechner, F. R. Knight, K. S. Athukorala Arachchige, R. A. M. Randall, M. Bühl, A. M. Z. Slawin, J. D. Woollins, Organometallics 2012, 31, 2922; e) L. A. Aschenbach, F. R. Knight, R. A. M. Randall, D. B. Cordes, A. Baggott, M. Bühl, A. M. Z. Slawin, J. D. Woollins, Dalton Trans. 2012, 41, 3141.f) M. W. Stanford, F. R. Knight, K. S. Athukorala Arachchige, P. Sanz Camacho, S. E. Ashbrook, M. Bühl, A. M. Z. Slawin, J. D. Woollins, Dalton Trans. 2014, 43(17), 6548.

[8] a) G. P. Petrenko, E. N. Tel'nyuk, Zh. Obshch. Khim. 1966, 2(4), 722; b) G. P. Petrenko, E. N. Tel'nyuk, Zh. Org. Chim. 1967, 3(1), 180; c) G. P. Petrenko, E. N. Tel'nyuk., Zh. Org. Khim. 1967, 3(5), 927; d) F. B. Mallory, C. W. Mallory, K. E. Butler, M. B. Lewis, A. Q. Xia, E. D. Luzik Jr., L. E. Fredenburgh, M. M. Ramanjulu, Q. N. Van, M. M. Francl, D. A. Freed, C. C. Wray, C. Hann, M. Nerz-Stormes, P. J. Carroll, L. E. Chirlian, J. Am. Chem. Soc. 2000, 122, 4108; e) V. A. Ozeryanskii, A. F. Pozharskii, G. R. Milgizina, S. T. Howard, J. Org. Chem. 2000, 65, 7707; f) A. N. Antonov, R. V. Tyurin, L. G. Minyaeva, V. V. Mezheritskii, Russ. J. Org. Chem. 2006, 42(10), 1576.

[9] a) B. K. Teo, F. Wudl, J. H. Marshall, A. Krugger, J. Am. Chem. Soc. 1977, 99, 2349; b) B. K. Teo, P. A. SnyderRobinson, Inorg. Chem. 1978, 17, 3489; c) B. K. Teo, P. A. Snyder-Robinson, Inorg. Chem. 1979, 18, 1490 ; d) B. K. Teo, P. A. Snyder-Robinson, Inorg. Chem. 1981, 20, 4235.

[10] S. M. Aucott, H. L. Milton, S. D. Robertson, A. M. Z. Slawin, G. D. Walker, J. D. Woollins, Chem. Eur. J. 2004, 10, 1666; S. D. Robertson, PhD Thesis, University of St Andrews (UK), 2005 and the references therein.

[11] C. G. M. Benson, C. M. Schofield, R. A. M. Randall, L. Wakefield, F. R. Knight, A. M. Z. Slawin, J. D. Woollins, Eur. J. Inorg. Chem. 2013, 427. 
[12] L-Y. Chiang and J. Meinwald, Tetrahedron Lett. 1980, 21, 4565.

[13] L. M. Diamond, F. R. Knight, K. S. Athukorala Arachchige, R. A. M. Randall, M. Bühl. A. M. Z. Slawin, J. D. Woollins, Eur. J. Inorg. Chem. 2014, 9, 1512.

[14] R. V. Parish, NMR, NQR, EPR, and Mössbauer Spectroscopy in Inorganic Chemistry, Ellis Horwood Limited, Chichester England, 1990.

[15] C. P. Morley, C. A. Webster, P. Douglas, K. Rofe, M. Di Vaira, Dalton Trans. 2010, 39, 3177.

[16] a) G. Matsubayahi, A. Yokozawa, Inorg. Chim. Acta. 1993, 208, 95; b) V. C. Ginn, P. F. Kelly, J. D. Woollins, Polyhedron 1994, 13(10), 1501; c) M. Risto, E. M. Jahr, M. S. Hannu-Kuure, R. Oilunkaniemi, R. S. Laitinen, J. Organomet. Chem. 2007, 692, 2193.

[17] J. A. Iggo (Ed.), NMR Spectroscopy in Inorganic Chemistry, Oxford University Press Inc., New York, 1999.

[18] R. Steudel, Angew. Chem. Int. Ed. Engl. 1975, 14(10), 655 and the references therein.

[19] W. H. Hersh, J. Chem. Ed. 1997, 74, 1485.

[20] D. Drew, J. R. Doyle, Inorg. Synth. 1972, 13, 47.

[21] F. J. Ramos-Lima, A. G. Quiroga, J. M. Pérez, M. Font-Bardía, X. Solans, C. Navarro-Ranninger, Eur. J. Inorg. Chem. 2003, 8, 1591.

[22] J. Bailar, H. Itatani, Inorg. Chem. 1965, 4, 1618.

[23] CrystalClear: Rigaku Corporation, 1999. CrystalClear Software User's Guide, Molecular Structure Corporation, (c) 2000. J. W. Pflugrath, Acta Cryst. 1999, D55, 1718-1725.

[24] SIR2004: M.C. Burla, R. Caliandro, M. Camalli, B. Carrozzini, G.L. Cascarano, L. De Caro, C. Giacovazzo, G. Polidori, R. Spagna, 2005.

[25] DIRDIF99: P. T. Beurskens, G. Admiraal, G. Beurskens, W. P. Bosman, R. de Gelder, R. Israel, J. M. M. Smits, 1999. The DIRDIF-99 program system, Technical Report of the Crystallography Laboratory, University of Nijmegen, The Netherlands.

[26] CrystalStructure 4.1: Crystal Structure Analysis Package, Rigaku Corporation (2000-2014). Tokyo 196-8666, Japan.

[27] SHELX2013: G. M. Sheldrick, 2013, University of Gottingen, Germany.

[28] OLEX2: O. V. Dolomanov, L. J. Bourhis, R. J. Gildea, J. A. K. Howard, H. Puschmann, J. Appl. Cryst. 2009, 42, 339. 


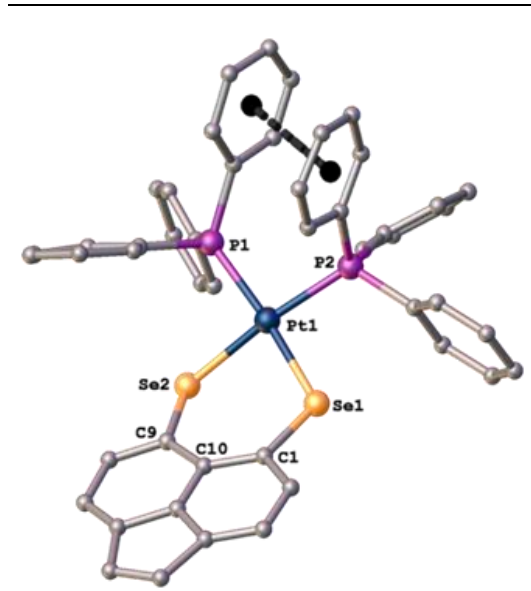

((Seven platinum bisphosphine complexes have been prepared from acenaphtho[5,6-cd]-1,2-dichalcogenoles AcenapylE $\mathrm{E}_{2} \mathrm{E}=\mathrm{S}$, Se, following metathetical addition of the dilithium precursors to cis- $\left[\mathrm{PtCl}_{2}\left(\mathrm{PR}_{3}\right)_{2}\right]\left(\mathrm{R}_{3}=\mathrm{Ph}_{3}\right.$, $\left.\mathrm{Ph}_{2} \mathrm{Me}, \quad \mathrm{PhMe}_{2}, \mathrm{Me}_{3}\right)$. $\quad[\operatorname{Pt}(5,6$-AcenapylS $)(\mathrm{COD})]$ was also prepared in a similar manner from (1,5cyclooctadiene)platinum(II) dichloride.)) 